\title{
One Hundred Years of Social Psychology Quantitatively Described
}

\author{
F. D. Richard \\ University of North Florida
}

\author{
Charles F. Bond Jr. and \\ Juli J. Stokes-Zoota \\ Texas Christian University
}

\begin{abstract}
This article compiles results from a century of social psychological research, more than 25,000 studies of 8 million people. A large number of social psychological conclusions are listed alongside meta-analytic information about the magnitude and variability of the corresponding effects. References to 322 meta-analyses of social psychological phenomena are presented, as well as statistical effect-size summaries. Analyses reveal that social psychological effects typically yield a value of $r$ equal to .21 and that, in the typical research literature, effects vary from study to study in ways that produce a standard deviation in $r$ of .15. Uses, limitations, and implications of this large-scale compilation are noted.
\end{abstract}

In 1898 Norman Triplett published an early experiment in social psychology, about an effect of the presence of others on task performance. In the 100 years since Triplett's investigation, many social psychological effects have been documented. The current article summarizes the best established of these findings, with data from more than 25,000 research studies and 8 million people. Our goal is to quantify the magnitude and variability of social psychological effects. We begin by considering previous summaries of social psychology, note some unresolved issues, and review developments that permit a century of scholarly work to be quantitatively described. For present purposes, we follow Manstead and Hewstone (1995) in regarding social psychology as the study of "the reciprocal influence of the individual and his or her social context" (p. 588).

\section{Social Psychology Summarized}

There are many summaries of social psychology. For undergraduates, there are textbooks

F. D. Richard, Department of Psychology, University of North Florida; Charles F. Bond Jr. and Juli J. Stokes-Zoota, Department of Psychology, Texas Christian University.

We are grateful to Alice Eagly, Bill Ickes, and Wendy Wood for comments on an earlier version of this article.

Correspondence concerning this article should be addressed to F. D. Richard, Department of Psychology, University of North Florida, 4567 St. Johns Bluff Road South, Jacksonville, Florida 32224, or Charles F. Bond Jr., Department of Psychology, Box 298920, Texas Christian University, Fort Worth, Texas 76129. E-mail: drichard@unf.edu or c.bond@tcu.edu (e.g., Lord, 1997). For the historically minded, there are chronologies (e.g., Sahakian, 1974). For specialists, edited handbooks of social psychology are periodically published (e.g., Gilbert, Fiske, \& Lindzey, 1998). For the educated lay public, an alphabetic encyclopedia of social psychology has appeared (Manstead \& Hewstone, 1995).

In light of these earlier efforts, one might imagine that the field of social psychology has been so thoroughly described that any additional description would be redundant. Yet, having read many of the field-wide summaries, we are left with some questions. For example, how large are the effects that social psychologists study? How variable are these effects? No empirically based answers to these questions can be found in any textbook, chronology, handbook, or encyclopedia we have seen.

There has been interest in the strength and variability of social psychological research findings. Some surmise that "many" social psychological effects are "small," reflecting relationships equivalent to a correlation coefficient of .10 (Cohen, 1988). Others report that the average effect cited in social psychology textbooks is much larger, approaching a correlation coefficient of .50 (Cooper \& Findley, 1982). Some believe that social psychological effects are inherently nonreplicable (Cronbach, 1975; Gergen, 1973). Others contend that many relationships of interest to social psychologists are perfectly stable and that their apparent variability is artifactual (Hunter \& Schmidt, 1990).

Contentions about the size and consistency of social psychological effects are important be- 
cause they bear on the scientific status of the field (Rosenthal, 1984). Previous generalizations about these effects have not, however, been well supported. Perhaps "many" social psychological effects are "small," but the scholar who offered this assertion acknowledged that it reflected only his "subjective averaging" (Cohen, 1988). Maybe the typical social psychological effect is "large," but at present this belief is based on 237 effects cited in textbooks. These particular effects may have been selected for textbook citation precisely because they were unusually large (Cooper \& Findley, 1982). Contentions about the replicability of social psychological effects have been based on individual scholars' experiences with a limited number of research literatures in social (Gergen, 1973), educational (Cronbach, 1975), and industrial/organizational psychology (Hunter \& Schmidt, 1990). In fact, the size and variability of most social psychological effects is at present unknown.

\section{Meta-Analyses in Social Psychology}

Generalizations about social psychological effects require a large-scale compilation of evidence that, until recently, would not have been possible. Such a compilation must draw on quantitative summaries of social psychological research literatures. These involve the use of techniques of meta-analysis (Glass, 1976; Rosenthal, 1984), described next.

A meta-analyst uncovers a number of studies on the same topic and then converts the effect observed in each study to a common metric, such as a Pearson product-moment correlation coefficient $(r)$. Each of the effect sizes is weighted by a term that reflects its precision, and a weighted mean effect size is computed to estimate the typical magnitude of the effect. Meta-analysts also examine the heterogeneity of effects in a particular research literature. They may compute the variance in effect sizes from study to study; however, as an estimate of heterogeneity, the total variance among effect sizes is deceptive (Hunter \& Schmidt, 1990). Statistical theory implies that effect sizes should vary from study to study by virtue of the fact that researchers investigate only samples of research participants, not populations. Meta-analysts use a homogeneity test to determine whether the effect sizes in a research literature vary more than one would expect from sampling variability. They can also estimate the variance in effect sizes that would have been observed in a research literature if an entire population had participated in each study. This so-called corrected variance is equal to the total variance in effect sizes minus the expected sampling variance (Hedges \& Vevea, 1998).

A few quantitative literature reviews had been published on social psychological topics before 1976, when Glass coined the term metaanalysis. Among these early efforts were quantitative reviews of leadership (Stogdill, 1948) and group discussion (Bass, 1954). After 1976, large numbers of social psychological metaanalyses began to appear. By 1997, hundreds had been published.

The present article presents a quantitative summary of a century of social psychological research. It seeks to compile quantitative reviews published on social psychological topics before 1998. Of interest is the mean size of the effect in each research literature, as well as the variability in effect sizes across studies. Accumulation of these data will permit rigorous generalizations about the typical magnitude and variability of social psychological research findings.

Although techniques for research synthesis had been available since the early 1900 s, metaanalysis was popularized later, as a method for coping with the "information explosion" in social research. Glass, McGaw, and Smith (1981) hoped that meta-analytic research integrations would be more succinct and widely accessible than narrative research reviews. From the current vantage point, one wonders whether these hopes have been fulfilled. Meta-analyses often run to more than 20 journal pages, and so many quantitative reviews have now been published that primary research may seem as inaccessible as ever.

If one goal of the current article is to offer generalizations about social psychology as a whole, a second goal is to provide the briefest possible summary of the many specific research literatures composing the field. To this end, we present a listing of social psychological effects that have been meta-analyzed. Each effect is stated alongside (a) the number of times the effect has been studied in primary research, (b) the mean size of the effect, and (c) a standard deviation in that effect across studies. Hundreds 
of such effects are summarized in this way, with references to the documents from which the effects were abstracted. These summaries are intended to increase the accessibility of social psychological research.

Indices of the magnitude and consistency of social psychological effects may have nonbibliographic uses as well. The mean size of a particular social psychological effect should help subject-area specialists in research planning and statistical power computation (Cohen, 1988). Cross-literature comparisons of effect sizes may help resolve some scholarly controversies. These data will, for example, permit the most complete comparison to date of the size of personality versus situational effects on social behavior (Bowers, 1973) and of the magnitude of sex effects on social behavior relative to other effects (Hall, 1998).

Perhaps the size of social psychological effects is influenced by the process of social psychological research. Perhaps social psychologists are attracted to unusually large effects, or to effects that are unusually stable. Perhaps there is a regular progression to social psychological research literatures: After an initial wave of studies that establish and replicate an effect, most studies are designed to find the limits and boundary conditions of the effect (Zanna \& Fazio, 1982). By making statistical comparisons of different research literatures, we assess these possibilities.

Although no large-scale compilation of social psychological meta-analyses has ever been attempted, there has been related work. Sarason, Smith, and Diener (1975) compiled results from 102 studies and concluded that situational effects on social behavior are similar in size to personality effects (median $r \mathrm{~s}=.21$ and .17 , respectively). Statistical interactions between situation and personality are smaller, the authors found. Hedges (1987) empirically gauged the consistency of research results in a number of fields. He showed that effect sizes in particle physics were no more consistent from study to study than effect sizes in several areas of psychology (e.g., cognitive gender differences).

Scholars have compiled meta-analyses in other fields. Lipsey and Wilson (1993) cumulated results from 302 meta-analytic reviews of the efficacy of psychological, educational, and behavioral treatments. Lipsey and Wilson offered a listing and histogram of mean effect sizes from these 302 quantitative reviews, as well as a number of statistical analyses. On average, people who received treatment scored one half of a standard deviation better on outcome variables than people who did not. This produced a treatment-outcome correlation coefficient of .24. Smaller scale compilations of meta-analyses have been reported in industrial/ organizational psychology (Tett, Meyer, \& Roese, 1994), on sex differences (Hall, 1998), and on the validity of laboratory research (Anderson, Lindsay, \& Bushman, 1999). Here we compile meta-analyses in social psychology and related fields.

\section{Method}

\section{Document Retrieval}

To locate published quantitative reviews of social psychological research, we used the following methods. We searched PsycLIT and other computerized databases for references to meta-analysis, examined a number of special journal issues and books on metaanalysis (e.g., Miller \& Cooper, 1991), used the Social Sciences Citation Index to locate documents that had cited certain key references on meta-analysis (e.g., Rosenthal, 1984), consulted lists of meta-analyses that had been compiled by others (e.g., Bausell, Li, Gau, \& Soeken, 1995), and manually scanned all of the issues of certain journals (e.g., Psychological Bulletin). Using these methods, we retrieved and photocopied 490 documents for possible inclusion in this work.

\section{Criteria for Inclusion}

Our goal was to compile quantitative summaries of social psychological effects published before 1998 . In selecting documents for this compilation, we used a number of criteria. To be included, a document had to report a numerical measure of the combined magnitude or significance level of a relationship between two variables that had been measured on individuals or small groups. The document had to summarize evidence of this effect collected within five or more primary studies by two or more research teams. The topic under review must have been covered in a recent encyclopedia of social psychology (Manstead \& Hewstone, 1995).

These criteria resulted in the exclusion of a number of potentially relevant documents. Narrative reviews of social psychological research were not included, nor were documents that reported only a vote counting of significant and nonsignificant results. We did not compile statistical summaries of a single research 
team's work, quantitative reviews of factor structure, or meta-analytic demonstrations of cross-study relationships. On substantive grounds, reviews of cognitive gender differences were excluded, as were reviews of educational, clinical, medical, marketing, and industrial/organizational research. To ensure the independence of our contribution, we also excluded reviews of all psychological topics that had been covered in Lipsey and Wilson's (1993) compendium of 302 meta-analyses on psychological treatment effectiveness.

Within the boundaries imposed by these criteria, we sought inclusive coverage of social psychological meta-analyses. We were open to reviews that had not been conducted by social psychologists and to reviews that had not appeared in the usual publication outlets, so long as they addressed topics that would qualify as social psychology, broadly defined. We were open to quantitative reviews of social psychological topics on which meta-analyses had previously been published, so long as the earlier meta-analytic database had been altered in some way. We also compiled reviews of many topics in personality psychology.

\section{Selection and Coding of Effects}

We selected for coding at least one social psychological effect from each document. Many meta-analysts begin by aggregating all of the literature on a topic into a single effect and then assess the magnitude of that effect in various subsets of the literature. Hoping to compile the broadest generalizations social psychologists find meaningful, we selected for coding the most highly aggregated effect a meta-analytic document displayed. Sometimes in their most highly aggregated analysis, meta-analysts summarize the literature on a topic into two or more distinct effects. In such cases, we coded these effects separately, including in our compilation up to four effects from a given document. From those rare documents that (in their most highly aggregated analyses) summarized a research literature into five or more distinct effects, we selected for compilation only four of those effects, preferring effects that had not been meta-analyzed elsewhere and ones that had been examined in a large number of studies.

We coded a summary measure of size of each effect. We used the meta-analyst's effect-size metric and whatever summary statistic the reviewer provided, seeking (when available) a weighted mean Fisher's $r$-to- $Z$ statistic. We then transformed the meta-analyst's summary effect size to a Pearson product-moment correlation coefficient according to methods described by Rosenthal (1994). We symbolize this value as $\bar{r}$.

Although meta-analysts usually report positive values for their summary effect sizes, 60 negative summary effect sizes were reported in the documents we retrieved. We analyzed the absolute value of the $\bar{r}$ corresponding to each summary effect size and we provide a statement of the meta-analytic finding. For example, we report an $\bar{r}$ value of .13 for the metaanalytic finding that women experience more anxiety than men, even though Feingold (1994) had expressed this effect as a negative standardized difference between means.

Each of the mean effect sizes in our compilation was independently coded by two of the authors. A preliminary analysis established interrater reliability $(r=.92$ for the relationship between the two sets of $\bar{r} \mathrm{~s})$. Coding differences were resolved by discussion.

We were interested not only in the magnitude of social psychological effects, but also in their variability. For each effect abstracted from a meta-analytic document, we sought the corrected variance in effect sizes, that is, the variance in effect size from study to study that could not be accounted for by differences among samples of research participants (Hedges \& Vevea, 1998). Some meta-analysts report a corrected (or true) variance. In such cases, the meta-analyst's value was coded. In other cases, we used a method of moments (Shadish \& Haddock, 1994) to estimate the corrected variance from information the meta-analyst reported, such as the number of studies being analyzed, the number of research participants, a homogeneity statistic, and a raw variance in effect sizes. Sometimes the requisite information was not reported, and the corrected variance could not be estimated. Corrected variance was estimated in the effect-size metric the meta-analyst had cumulated and then converted to a corrected variance for Pearson product-moment correlation coefficients with Taylor series approximations (e.g., Law, 1995). Occasionally, these procedures resulted in a negative estimate. In such cases, a value of zero was substituted. We report subsequently the square root of our estimate of the corrected variance in correlation coefficients, that is, the corrected standard deviation in $r$ from study to study. From each research literature that allowed it, we also coded the total variance in effect sizes from study to study.

\section{Additional Coding}

Effects may be larger in some research literatures than others. The variability in effect sizes may differ from literature to literature. To clarify cross-literature differences in effect sizes, we coded four additional variables from each meta-analysis: (a) number of primary effect-size estimates, (b) proportion of unpublished research, (c) number of theoretical moderator analyses, and (d) number of artifactual moderator analyses. These variables are described next.

Meta-analysts base their conclusions on differing amounts of data. There are two indices of the quantity 
of data that enter into a meta-analytic conclusion: the number of primary research studies on which that conclusion is based and the number of primary effectsize estimates. Often, meta-analysts abstract multiple effect-size estimates from a single research study. For our statement of the total number of research studies included in the current compilation, we took care to avoid double counting studies from which multiple effect sizes had been abstracted. However, this double counting could not be avoided in the appended listing of effects. There we note the number of primary effect-size estimates on which a meta-analytic conclusion was based. This value is symbolized as $k$.

Publication practices may compromise the validity of scholarly conclusions. To address this concern, we perused the references to the primary studies on which each meta-analysis was based and noted the proportions of studies that were unpublished.

Some research literatures may consist solely of studies that seek to document and replicate an effect. Others may consist largely of studies that seek to neutralize an effect documented earlier. To capture this difference, we read each meta-analytic document carefully, looking for attempts to relate effect sizes to moderator variables. As a proxy for primary researchers' attempts to neutralize the focal effect of a research literature, we coded the number of psychological moderator variables examined in the metaanalysis of that literature. For comparison, we also coded the number of artifactual moderator variables examined.

\section{Results}

Our search yielded 322 codable meta-analytic documents spanning more than 6,200 pages of text. As mentioned, these documents incorporated results from more than 25,000 research studies and 8 million human research participants. References to the 322 documents appear in Appendix A. From these documents, we abstracted 474 effects, reflecting a considerable amount of data (mean $k=71.54$ ).

Appendix B lists these 474 social psychological effects. The effects are organized under 18 social psychological topic headings (e.g., aggression and attitudes). Alongside a statement of each meta-analytically established effect is the number of estimates of that effect $(k)$, the mean size of the effect (expressed as $\bar{r}$ ), the corrected standard deviation in $r$ across studies, and a numerical reference to the meta-analytic document from which the effect was abstracted (i.e., to the reference list of Appendix A). Note that the standard deviation in effect sizes was not always estimable. For example, the first row in Appendix B indicates that Document 176 of Appendix A (i.e., the meta-analysis by Miles \& Carey, 1997) concluded from 42 effect-size estimates that "there are genetic influences on aggressiveness," that the mean size of this effect corresponds to a correlation coefficient of .49 , and that the corrected standard deviation in this effect across studies cannot be estimated. In some cases, several documents reached the same social psychological conclusion from different meta-analytic databases. In such cases, a separate effect was coded from each document. For instance, three documents (Documents 39, 40, and 143 in Appendix A) concluded that "when people drink alcohol, they become aggressive."

Appendix B is intended to provide information about effect sizes, not statistical significance. We attempted to include in this appendix every social psychological effect that satisfied the criteria described in the Method section, irrespective of the outcome of a null hypothesis test. Each statement in the appendix expresses the direction of the corresponding mean effect, even if it was not statistically significant. For significance levels, substantive qualifications, and additional information about any of the 474 social psychological effects listed in Appendix $\mathrm{B}$, the relevant meta-analysis should be read.

Appendix B is intended as a reference source. It is keyed to a narrative encyclopedia of social psychology (Manstead \& Hewstone, 1995). The 18 topic headings in the appendix appear in the encyclopedia, as does each italicized term. The encyclopedia should be consulted for explanations of these terms and descriptions of relevant scholarship.

\section{Magnitude of Social Psychological Effects}

Some suspect that "many" social psychological effects are small, corresponding in size to a correlation coefficient of .10 (Cohen, 1988). Others report that social psychology textbooks cite large effects, ones that approach a correlation coefficient of .50. Figure 1 presents a histogram of the mean size of the 474 social psychological effects listed in Appendix B. Each effect was established by a meta-analysis and is expressed in the histogram by the absolute value of a Pearson product-moment correlation coefficient. As the figure reveals, social psychological effects vary in size. Their distribution is 


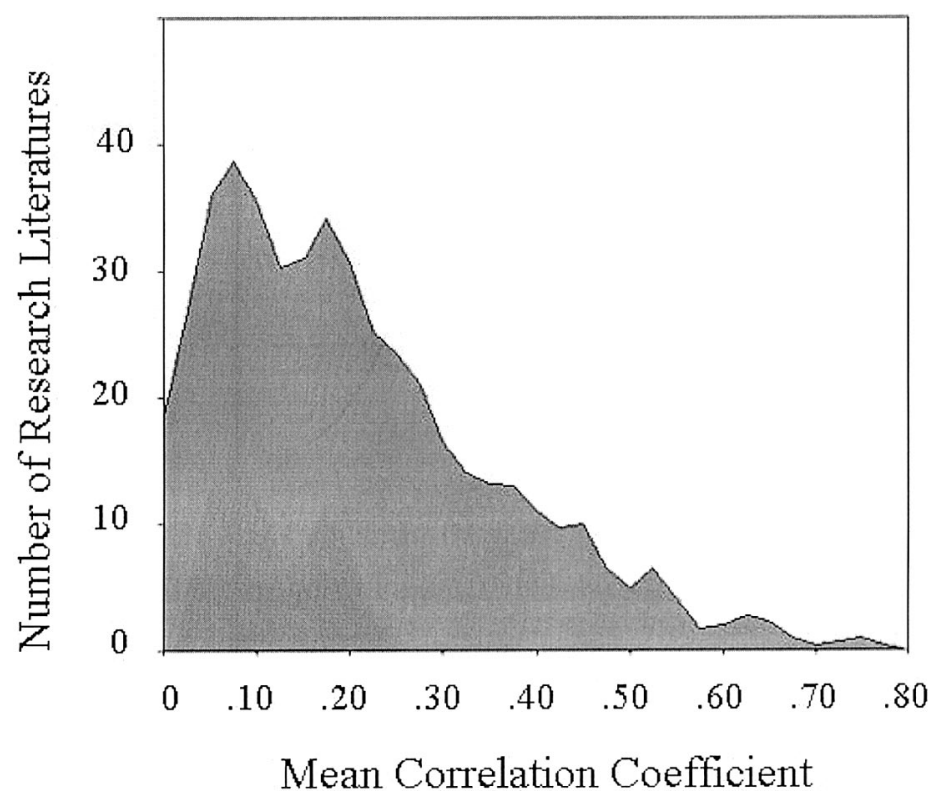

Figure 1. Magnitude of meta-analytic effect sizes in social psychology.

positively skewed. Although many of these effects are small (30.44\% yielding an $r$ of .10 or less), many others are not $(23.68 \%$ yielding an $r$ of .30 or more). Only $5.28 \%$ yield a value of $r$ greater than .50 . In this, the largest-scale social psychological database yet compiled, social psychological effects yield a mean value of $\bar{r}$ of $.21(M d n \bar{r}=.18$; across-literatures $S D=.15)$. Recall that 302 meta-analyses showed a mean correlation of .24 between psychological treatments and outcomes (Lipsey \& Wilson, 1993).

Journal referees may block publication of nonsignificant research findings (Greenwald, 1975). In principle, this publication bias might influence our estimate of the size of social psychological effects. To assess this possibility, we divided the 474 meta-analytic effects in Appendix B into three categories based on the percentage of unpublished studies cited in the corresponding meta-analytic document. Analyses indicated only a modest relationship between the magnitude of a social psychological effect and the percentage of unpublished studies on which it was based. One hundred seventy-five metaanalytic effects drawn from documents that cited no unpublished studies yielded a mean $\bar{r}$ value of .216; 208 effects drawn from documents whose reference lists included a range of
$1 \%-25 \%$ unpublished studies yielded a mean value of $\bar{r}$ of .202; and 91 meta-analytic effects drawn from documents whose reference lists included more than 25\% unpublished studies yielded a mean value of $\bar{r}$ of .199. Publication biases seem to have had little impact on our aggregate estimate of social psychological effect sizes.

Social psychologists study a variety of topics, some of which may show larger effects than others. Although social psychological research can be categorized in a number of ways, it is categorized in Appendix B under 18 topic headings: aggression, attitudes, attribution, expectancy effects, gender roles, group processes, health psychology, helping behavior, intergroup relations, law, leadership, methodology, motivation, nonverbal communication, personality, relationships, social cognition, and social influence.

Table 1 summarizes meta-analytic effects on each of these 18 topics. Listed in the table are the number of social psychological conclusions that have been reached about each topic, the number of primary research estimates on which those conclusions are based (total $k$ ), the mean size of the effect (expressed as $\bar{r}$ ), and the mean estimate of the corrected standard deviation in $r$ 
Table 1

Social Psychological Effect Sizes, by Topic

\begin{tabular}{lcccc}
\hline \multicolumn{1}{c}{ Topic } & $\begin{array}{c}\text { No. of } \\
\text { meta-analytic conclusions }\end{array}$ & $\begin{array}{c}\text { Total } \\
k\end{array}$ & $\begin{array}{c}\text { Mean } \\
\bar{r}\end{array}$ & $\begin{array}{c}\text { Mean corrected } \\
S D\end{array}$ \\
\hline Aggression & 31 & 3,323 & .24 & .20 \\
Attitudes & 32 & 2,476 & .27 & .14 \\
Attribution & 36 & 1,929 & .14 & .14 \\
Expectancy effects & 16 & 902 & .16 & .22 \\
Gender roles & 19 & 1,243 & .18 & .13 \\
Group processes & 27 & 1,183 & .32 & .15 \\
Health psychology & 22 & 2,340 & .17 & .13 \\
Helping behavior & 14 & 824 & .18 & .16 \\
Intergroup relations & 28 & 1,542 & .19 & .18 \\
Law & 25 & 1,374 & .17 & .08 \\
Leadership & 42 & 2,588 & .25 & .18 \\
Methodology & 29 & 2,356 & .21 & .10 \\
Motivation & 12 & 1,099 & .15 & .12 \\
Nonverbal communication & 29 & 1,471 & .22 & .17 \\
Personality & 32 & 3,905 & .21 & .14 \\
Relationships & 32 & 2,203 & .22 & .12 \\
Social cognition & 22 & 1,526 & .20 & .19 \\
Social influence & 26 & 1,629 & .13 & .18 \\
$\quad$ Overall & 474 & 33,912 & .21 & .15 \\
\hline
\end{tabular}

across studies. As the table indicates, more meta-analyses are published on leadership than on motivation or helping behavior. The largest mean effects were found in the study of attitudes (mean $\bar{r}=.27$ ) and group processes (mean $\bar{r}=.32$ ). The smallest were found in the study of attribution (mean $\bar{r}=.14$ ) and social influence (mean $\bar{r}=.13$ ). It is noteworthy, however, that these effects did not range as widely as one might have expected. In fact, none of the 18 social psychological topic areas in Table 1 yielded a mean correlation coefficient as low as .10 (the value that Cohen stated would describe "many social psychological effects"), nor did any of the topic areas yield a mean correlation coefficient as high as .50 (the typical size of effects cited in social psychology textbooks, according to Cooper \& Findley, 1982).

Inspired by criticisms of traditional conceptions of personality (Mischel, 1968), psychologists have debated whether social behavior is more strongly influenced by the person or the situation (Bowers, 1973). Of the 474 effects in our compilation, 247 involved assessments of the relationship of social behavior to a situational variable; 227 involved assessments of the relationship of social behavior to a demographic, personality, or other dispositional variable. Analyses showed that situational effects are similar in magnitude to person effects (mean $\bar{r}=.22$ in 17,631 estimates of situational effects; mean $\bar{r}=.19$ in 16,282 estimates of person effects). Situational effects may be slightly larger.

There have been arguments about the magnitude of sex differences. Psychological sex differences have been variously characterized as small, large, and highly variable in size (Hall, 1998). Appendix B lists 83 meta-analytically established sex differences: 16 in attribution, 14 in relationships, 10 in nonverbal communication, and 43 on other topics. These differences tend to be small: mean $\bar{r}=.12$ for 5,691 estimates of sex differences and mean $\bar{r}=.22$ for 28,222 estimates of other social psychological effects. Differences in reactions to female and male targets are smaller than differences produced by female and male actors (mean $\bar{r} \mathrm{~s}=$ .08 and .13 for sex of target effects and sex of actor effects, respectively). These sex differences are not especially variable across literatures: Cross-literature standard deviations in $\bar{r}$ values are .10 for the 83 sex differences and .15 for the 391 other meta-analytic effects (note that the current compilation is confined to sex differences on social psychological variables; for a treatment of cognitive sex differences, see Hall, 1998). 


\section{Variability of Social Psychological Effects}

Researchers who are interested in the typical magnitude of an effect may also be interested in the variability of that effect from study to study. Here we sought to document the variability of social psychological effects by determining, in each of 474 research literatures, a corrected standard deviation, that is, the standard deviation in effect sizes across studies that would have been observed in the absence of sampling variability. This task proved to be challenging. Meta-analysts reported a corrected standard deviation (or variance) for only 61 of the 474 social psychological effects in Appendix B, and many meta-analytic documents do not include sufficient information for standard deviations to be estimated. However, in the 355 literatures that do allow its computation, the corrected standard deviation in correlation coefficients varies in magnitude.

These estimates are presented for 355 of the social psychological effects listed in Appendix B. Statistical summaries indicate that some social psychological literatures show no variability in effect sizes beyond that which is introduced by sampling error $(9.29 \%$ of the 355 literatures yielding a corrected standard deviation of zero). Others show high study-to-study variability in effect sizes $(9.86 \%$ yielding a corrected standard deviation of .30 or higher). The mean estimate of the corrected standard deviation is $.15(M d n=.14$; across-literatures $S D=$ .10). It is interesting that the mean corrected standard deviation within a social psychological research literature is similar in magnitude to the standard deviation across the mean effect sizes of all 474 literatures. Each of these standard deviations equals .15 .

For each research literature from which a corrected standard deviation in effect sizes could be estimated, we also estimated a total standard deviation as well as the percentage of variance accounted for by sampling error. Across 355 research literatures, our mean estimate of the total standard deviation in correlation coefficients is .19.

Hunter and Schmidt (1990) contended that much of the variability observed in research is artifactual. Our data support this contention. Averaging across 355 social psychological research literatures, sampling variance accounts for a mean of $38.89 \%$ of the variance in effect sizes. In 59 of these literatures, sampling variance accounts for more than $75 \%$ of the variance in effect sizes.

\section{Correlates of Effect-Size Variability and Magnitude}

The number of studies conducted on a social psychological topic may reflect the research community's interest in that topic. Theoretically, researchers' interest in an effect might be related to the magnitude or variability of the effect. Analyses of the current database reveal no relationship between the number of studies of a social psychological effect and the mean size of that effect $(r=-.04)$. However, effects that are widely studied tend to be highly variable: $r=.11$ for the relationship between $k$ and corrected $S D$. Perhaps social psychologists are attracted to inherently unstable effects. More likely, as research literatures mature, scholars turn their attention from demonstrating an effect to identifying limits and boundary conditions of that effect (Zanna \& Fazio, 1982).

Often, meta-analysts abstract variables from a research literature to explain effect-size differences. To understand the heterogeneity in social psychological effects, we examined each of the 322 meta-analytic documents listed in Appendix A and found that 300 analyzed at least one moderator variable. We counted the number of artifactual and the number of psychological moderator variables meta-analyzed in each document.

Perhaps research literatures grow as social psychologists turn their attention from demonstrating an effect to finding limits and boundary conditions of that effect. Perhaps these efforts produce effect-size variability. Given this characterization of the research process, there should be more psychological moderator variables in large than small research literatures. Moreover, the greater the number of psychological moderator variables in a literature, the more variable should be the effect sizes.

Our data confirm these hypotheses. Across the 474 effects in Appendix B, the number of psychological moderator analyses in the associated meta-analytic document is positively associated with $k(r=.25)$ and is positively associated with the corrected $S D(r=.15)$. This pattern is specific to psychological moderator analyses. In fact, the corrected standard devia- 
tion of a social psychological effect is not related to the number of artifactual moderator variables examined in a meta-analysis of that effect $(r=.08)$.

Social psychologists' attempts to neutralize or reverse a focal finding may deflate the mean effect size in a research literature. Our results are consistent with this suggestion: The mean size of an effect is inversely related to the number of psychological moderator analyses of that effect $(r=-.12)$ but unrelated to the number of artifactual moderator analyses $(r=.06)$.

\section{Discussion}

Social psychology has grown over the past century. At the dawn of the 1900s, its experimental database consisted of a single study (Triplett, 1898). More studies were conducted, and much was learned. Later, scholars began to question the evidentiary value of individual studies (Schmidt, 1992) and developed methods for synthesizing all of the research on a particular topic (Glass et al., 1981). Now hundreds of research literatures have been meta-analyzed, and social psychology can be quantitatively described.

As a description of social psychology, the present effort has shortcomings. It is restricted to research that has been meta-analyzed and to research topics that were covered in a recent version of the Encyclopedia of Social Psychology. It may omit many important social psychological phenomena, particularly those at the boundaries of the field. No doubt, there are complications, qualifications, and subtleties to every social psychological phenomenon that could never be captured in descriptions as brief as the one-line summaries appended here. Moreover, the magnitude of a social psychological effect does not determine the value of that effect. A small effect can have important realworld consequences (Rosenthal, 1994). A small effect can hold great scientific interest if, for example, it is produced by a small cause (Abelson, 1995). Despite its limitations, this is the largest social psychological database ever assembled. It allows the most rigorous generalizations to date about the magnitude of social psychological effects.

Cohen (1988) provided some guidelines for effect sizes. According to Cohen, "many" effects in social psychology would yield a corre- lation coefficient of .10 , and such values are small. Cohen defined medium-sized effects as those that yield a correlation coefficient of .30 . Large effects, he stated, are those that yield a correlation coefficient of at least .50. Cohen, however, cautioned that these guidelines reflected only his "subjective averaging," and he recommended that they be used only when there was "no better basis" for identifying small, medium, and large effects.

The current review provides an empirical basis for gauging the size of social psychological effects. It indicates that a correlation coefficient of .10 is "small" relative to most social psychological effects. Mean effects this small are found in roughly $30 \%$ of social psychological research literatures. It indicates that a correlation coefficient of .20 is a medium-sized effect. Effects that small are found in roughly half of the relevant literatures. A correlation coefficient of .30 is large relative to most social psychological effects. Less than $25 \%$ of mean effects are that large.

Although general reference values for "small," "medium," and "large" effects can be used in statistical power computation, it is better to base such computations on information that is specific to the research question being posed. Appendix $\mathrm{B}$ presents quantitative data for a large number of social psychological effects. Researchers who plan work on one of these effects should consult this appendix for the mean size of that effect in previous research. This value would be a good starting point for power computations.

Social psychological effects vary considerably from study to study, but much of this variation is artifactual. In a typical social psychological research literature, almost $40 \%$ of the cross-study variance in effects can be accounted for by differences among research samples. Even after correction for sampling error, however, substantial effect-size variance remains. No doubt, some of this residual variance is due to artifacts such as measurement error (Hunter \& Schmidt, 1990). Variance is also introduced by social psychologists' attempts to manipulate effects (Zanna \& Fazio, 1982). In our view, each standard deviation listed in Appendix B should be regarded as an upper bound to the value that would be obtained in a series of attempts at exact replication and as a lower bound to the impact on the effect of a typical 
moderator variable. In literatures in which most of the studies are designed to document a focal effect, our standard deviation may be a reasonable measure of effect-size consistency. In literatures in which most of the studies are intended to reverse an effect, our standard deviation may better measure the effect's manipulability. In light of these considerations, scholars should be cautious in comparing effectsize variability across research literatures.

The mean effect size yielded by a meta-analysis also requires judicious interpretation. Metaanalytic means (such as those listed in Appendix B) incorporate effects from a variety of conditions, settings, and research designs. Strong conclusions can be reached from research literatures that show homogeneous effect sizes. There, the mean is estimating a single effect. However, in research literatures that contain highly heterogeneous findings, it would be naive to interpret the mean size of an effect as the magnitude of that effect under any particular set of conditions (say, conditions that specialists regard as standard or theoretically prescribed). A social psychological effect may be larger under standard conditions than is the mean effect in the literature as a whole, the mean having been deflated by investigators' attempts to neutralize and reverse the usual finding.

Narrative reviews of social psychology have presented rich interpretations of verbally stated effects (e.g., Gilbert et al., 1998). Here we have offered a quantitative description.

\section{References}

Abelson, R. P. (1995). Statistics as principled argument. Hillsdale, NJ: Erlbaum.

Anderson, C. A., Lindsay, J. J., \& Bushman, B. J. (1999). Research in the psychology laboratory: Truth or triviality? Current Directions in Psychological Science, 8, 3-9.

Bass, B. M. (1954). The leaderless group discussion. Psychological Bulletin, 51, 465-492.

Bausell, R. B., Li, Y., Gau, M., \& Soeken, K. L. (1995). The growth of the meta-analytic literature from 1980 to 1993. Evaluation and the Health Professions, 18, 238-251.

Bowers, K. S. (1973). Situationism in psychology: An analysis and a critique. American Psychologist, 80, 307-336.

Cohen, J. (1988). Statistical power analysis for the behavioral sciences (2nd ed.). New York: Academic Press.
Cooper, H., \& Findley, M. (1982). Expected effect sizes: Estimates for statistical power analysis in social psychology. Personality and Social Psychology Bulletin, 8, 168-173.

Cronbach, L. J. (1975). Beyond the two disciplines of scientific psychology. American Psychologist, 30, $116-127$.

Feingold, A. (1994). Gender differences in personality: A meta-analysis. Psychological Bulletin, 116, 429-456.

Gergen, K. (1973). Social psychology as history. Journal of Personality and Social Psychology, 26, 309-320.

Gilbert, D. T., Fiske, S. T., \& Lindzey, G. (1998). The handbook of social psychology (4th ed.). New York: Oxford University Press.

Glass, G. V. (1976). Primary, secondary, and metaanalysis of research. Educational Researcher, 5, $3-8$.

Glass, G. V., McGaw, B., \& Smith, M. L. (1981). Meta-analysis in social research. Beverly Hills, CA: Sage.

Greenwald, A. G. (1975). Consequences of prejudice against the null hypothesis. Psychological Review, 82, 1-20.

Hall, J. A. (1998). How big are nonverbal sex differences? In D. J. Canary \& K. Dindia (Eds.), Sex differences and similarities in communication (pp. 155-177). Mahwah, NJ: Erlbaum.

Hedges, L. V. (1987). How hard is hard science, how soft is soft science: The empirical cumulativeness of research. American Psychologist, 42, 443-455.

Hedges, L. V., \& Vevea, J. L. (1998). Fixed- and random-effects models in meta-analysis. Psychological Methods, 3, 486-504.

Hunter, J. E., \& Schmidt, F. L. (1990). Methods of meta-analysis: Correcting error and bias in research findings. Newbury Park, CA: Sage.

Law, K. S. (1995). The use of Fisher's Z in HunterSchmidt-type meta-analyses. Journal of Educational and Behavioral Statistics, 20, 287-306.

Lipsey, M. W., \& Wilson, D. B. (1993). The efficacy of psychological, educational, and behavioral treatment: Confirmation from meta-analysis. American Psychologist, 48, 1181-1209.

Lord, C. G. (1997). Social psychology. Orlando, FL: Harcourt Brace.

Manstead, A. S. R., \& Hewstone, M. (1995). The Blackwell encyclopedia of social psychology. Cambridge, MA: Blackwell.

Miller, N., \& Cooper, H. M. (1991). Introduction to special issue on meta-analysis in personality and social psychology. Personality and Social Psychology Bulletin, 17, 243-244.

Mischel, W. (1968). Personality and assessment. New York: Wiley.

Rosenthal, R. (1984). Meta-analytic procedures for social research. Newbury Park, CA: Sage. 
Rosenthal, R. (1994). Parametric measures of effect size. In H. Cooper \& L. V. Hedges (Eds.), The handbook of research synthesis (pp. 231-244). New York: Russell Sage Foundation.

Sahakian, W. S. (1974). Systematic social psychology. New York: Chandler.

Sarason, I. G., Smith, R. E., \& Diener, E. (1975). Personality research: Components of variance attributable to the person and the situation. Journal of Personality and Social Psychology, 32, 199204.

Schmidt, F. L. (1992). What do data really mean? Research findings, meta-analysis, and cumulative knowledge in psychology. American Psychologist, 47, 1173-1181.

Shadish, W. R., \& Haddock, C. K. (1994). Combining estimates of effect size. In H. Cooper \& L. V. Hedges (Eds.), The handbook of research synthesis (pp. 261-281). New York: Russell Sage Foundation.

Stogdill, R. M. (1948). Personal factors associated with leadership: A survey of the literature. Journal of Psychology, 25, 35-71.

Tett, R. P., Meyer, J. P., \& Roese, N. J. (1994). Applications of meta-analysis: 1987-1992. International Review of Industrial and Organizational Psychology, 9, 71-112.

Triplett, N. (1898). The dynamogenic factors in pacemaking and competition. American Journal of Psychology, 9, 507-533.

Zanna, M. P., \& Fazio, R. H. (1982). The attitudebehavior relation: Moving toward a third generation of research. In M. P. Zanna, E. T. Higgins, \& C. P. Herman (Eds.), Consistency in social behavior: The Ontario Symposium (Vol. 2, pp. 283301). Hillsdale, NJ: Erlbaum.

\section{Appendix A}

\section{Meta-Analyses in Social Psychology}

1. Ackerman, P. L., \& Heggestad, E. D. (1997). Intelligence, personality, and interests: Evidence for overlapping traits. Psychological Bulletin, 121, 219-245.

2. Adair, J. G., Sharpe, D., \& Huynh, C. (1989). Hawthorne control procedures in educational research: A reconsideration of their use and effectiveness. Review of Educational Research, 59, 215-228.

3. Aguinis, H., Pierce, C. A., \& Quigley, B. M. (1993). Conditions under which a bogus pipeline procedure enhances the validity of self-reported cigarette smoking: A meta-analytic review. Journal of Applied Social Psychology, 23, 352-373.

4. Aguinis, H., Pierce, C. A., \& Quigley, B. M. (1995). Enhancing the validity of self-reported alcohol and marijuana consumption using a bogus pipeline: A meta-analytic review. Basic and Applied Social Psychology, 16, 515-527.

5. Ajzen, I. (1991). The theory of planned behavior. Organizational Behavior and Human Decision Processes, 50, 179-211.

6. Allen, M. (1991). Meta-analysis comparing the persuasiveness of one-sided and two-sided messages. Western Journal of Speech Communication, 55, 390-404.

7. Allen, M., D’Alessio, D., \& Brezgel, K. (1995). A meta-analysis summarizing the effects of pornog- raphy II: Aggression after exposure. Human Communication Research, 22, 258-283.

8. Allen, M., Emmers, T., Gebhardt, L., \& Giery, M. A. (1995). Exposure to pornography and acceptance of rape myths. Journal of Communication, 45, 5-26.

9. Allen, M., D’Alessio, D., Emmers, T. M., \& Gebhardt, L. (1996). The role of educational briefings in mitigating effects of experimental exposure to violent sexually explicit material: A meta-analysis. The Journal of Sex Research, 33, 135-141.

10. Allen, M., Donohue, W., \& Stewart, B. (1990). Comparing hardline and softline bargaining strategies in zero-sum situations using meta-analysis. In M. A. Rahim (Ed.), Theory and research in conflict management (pp. 86-103). New York: Praeger.

11. Allen, M., \& Stiff, J. B. (1989). Testing three models for the sleeper effect. Western Journal of Speech Communication, 53, 411-426.

12. Ambady, N., \& Rosenthal, R. (1992). Thin slices of expressive behavior as predictors of interpersonal consequences: A meta-analysis. Psychological Bulletin, 111, 256-274.

13. Anderson, C. A., \& Bushman, B. J. (1997). External validity of "trivial" experiments: The case of laboratory aggression. Review of General Psychology, 1, 19-41. 
14. Anderson, K. B., Cooper, H., \& Okamura, L. (1997). Individual differences and attitudes toward rape: A meta-analytic review. Personality and Social Psychology Bulletin, 23, 295-315.

15. Anderson, L. R., \& Blanchard, P. N. (1982). Sex differences in task and social-emotional behavior. Basic and Applied Social Psychology, 3, 109-139.

16. Anderrson, G. (1996). The benefits of optimism: A meta-analytic review of the Life Orientation Test. Personality and Individual Differences, 21, 719-725.

17. Andresen, P. A., \& Telleen, S. L. (1992). The relationship between social support and maternal behaviors and attitudes: A meta-analytic review. American Journal of Community Psychology, 20, 753-774.

18. Anthony, T., Copper, C., \& Mullen, B. (1992). Cross-racial facial identification: A social cognitive integration. Personality and Social Psychology Bulletin, 18, 296-301.

19. Archer, J. (1989). The relationship between gender-role measures: A review. British Journal of Social Psychology, 28, 173-184.

20. Archer, J. (1991). The influence of testosterone on human aggression. British Journal of Psychology, 82, 1-28.

21. Arkin, R. M., Cooper, H. M., \& Kolditz, T. A. (1980). A statistical review of the literature concerning the self-serving attribution bias in interpersonal influence situations. Journal of Personality, 48, 435-448.

22. Armstrong, J. S., \& Lusk, E. (1987). Return postage in mail surveys: A meta-analysis. Public Opinion Quarterly, 51, 233-248.

23. Bass, B. M. (1954). The leaderless group discussion. Psychological Bulletin, 51, 465-492.

24. Beaman, A. L., Cole, C. M., Preston, M., Klentz, B., \& Steblay, N. M. (1983). Fifteen years of foot-in-the-door research: A meta-analysis. Personality and Social Psychology Bulletin, 9, 181-196.

25. Beaman, A. L., \& Klentz, B. (1983). The supposed physical attractiveness bias against supporters of the women's movement: A meta-analysis. Personality and Social Psychology Bulletin, 9, $544-550$.

26. Benassi, V. A., Sweeney, P. D., \& Dufour, C. L. (1988). Is there a relation between locus of control orientation and depression? Journal of Abnormal Psychology, 97, 357-367.

27. Bettencourt, B. A., \& Kernahan, C. (1997). A meta-analysis of aggression in the presence of violent cues: Effects of gender differences and aversive provocation. Aggressive Behavior, 23, 447-456.

28. Bettencourt, B. A., \& Miller, N. (1996). Gender differences in aggression as a function of provocation: A meta-analysis. Psychological Bulletin, 119, 422-447.
29. Bond, C. F., Jr., \& Titus, L. J. (1983). Social facilitation: A meta-analysis of 241 studies. Psychological Bulletin, 94, 265-292.

30. Bond, R., \& Smith, P. B. (1996). Culture and conformity: A meta-analysis of studies using Asch's (1952b, 1956) line judgment task. Psychological Bulletin, 119, 111-137.

31. Booth-Butterfield, S. (1988). A meta-analysis of the cross-situational consistency of communication apprehension. Communication Research Reports, 5, 64-70.

32. Bornstein, R. F. (1989). Exposure and affect: Overview and meta-analysis of research, 19681987. Psychological Bulletin, 106, 265-289.

33. Bornstein, R. F. (1994). Dependency as a social cue: A meta-analytic review of research on the dependency-helping relationship. Journal of Research in Personality, 28, 182-213.

34. Boster, F. J., \& Mongeau, P. (1984). Fear-arousing persuasive messages. Communication Yearbook, 8, 330-375.

35. Bothwell, R. K., Brigham, J. C., \& Malpass, R. S. (1989). Cross-racial identification. Personality and Social Psychology Bulletin, 15, 19-25.

36. Bothwell, R. K., Deffenbacher, K. A., \& Brigham, J. C. (1987). Correlation of eyewitness accuracy and confidence: Optimality hypothesis revisited. Journal of Applied Psychology, 72, 691-695.

37. Buller, D. B. (1986). Distraction during persuasive communication: A meta-analytic review. Communication Monographs, 53, 91-114.

38. Burger, J. M. (1981). Motivational biases in the attribution of responsibility for an accident: A meta-analysis of the defensive-attribution hypothesis. Psychological Bulletin, 90, 496-512.

39. Bushman, B. J. (1997). Effects of alcohol on human aggression: Validity of proposed explanations. Recent Developments in Alcoholism, 13, 227-243.

40. Bushman, B. J., \& Cooper, H. M. (1990). Effects of alcohol on human aggression: An integrative research review. Psychological Bulletin, 107, 341-354.

41. Cacioppo, J. T., Petty, R. E., Feinstein, J. A., \& Jarvis, W. B. G. (1996). Dispositional differences in cognitive motivation: The life and times of individuals varying in need for cognition. Psychological Bulletin, 119, 197-253.

42. Cameron, J., \& Pierce, W. D. (1994). Reinforcement, reward, and intrinsic motivation: A metaanalysis. Review of Educational Research, 64, 363-423.

43. Carlson, M., Charlin, V., \& Miller, N. (1988). Positive mood and helping behavior: A test of six hypotheses. Journal of Personality and Social Psychology, 55, 211-229.

44. Carlson, M., Marcus-Newhall, A., \& Miller, N. (1989). Evidence for a general construct of aggres- 
sion. Personality and Social Psychology Bulletin, 15, 377-389.

45. Carlson, M., Marcus-Newhall, A., \& Miller, N. (1990). Effects of situational aggression cues: A quantitative review. Journal of Personality and Social Psychology, 58, 622-633.

46. Carlson, M., \& Miller, N. (1987). Explanation of the relation between negative mood and helping. Psychological Bulletin, 102, 91-108.

47. Carlson, M., \& Miller, N. (1988). Bad experiences and aggression. Sociology and Social Research, 72, 155-157.

48. Carron, A. V., Hausenblas, H. A., \& Mack, D. (1996). Social influence and exercise: A metaanalysis. Journal of Sport \& Exercise Psychology, 18, 1-16.

49. Carson, P. P., Carson, K. D., \& Roe, C. W. (1993). Social power bases: A meta-analytic examination of interrelationships and outcomes. Journal of Applied Social Psychology, 23, 1150-1169.

50. Christensen-Szalanski, J. J. J., \& Willham, C. F. (1991). The hindsight bias: A meta-analysis. Organizational Behavior and Human Decision Processes, 48, 147-168.

51. Church, A. H. (1993). Estimating the effect of incentives on mail survey response rates: A metaanalysis. Public Opinion Quarterly, 57, 62-79.

52. Churchill, G. A., Jr., \& Peter, J. P. (1984). Research design effects on the reliability of rating scales: A meta-analysis. Journal of Marketing Research, 21, 360-375.

53. Cohn, L. D. (1991). Sex differences in the course of personality development: A meta-analysis. Psychological Bulletin, 109, 252-266.

54. Coleman, H. L. K., Wampold, B. E., \& Casali, S. L. (1995). Ethnic minorities' ratings of ethnically similar and European American counselors: A meta-analysis. Journal of Counseling Psychology, 42, 55-64.

55. Collins, N. L., \& Miller, L. C. (1994). Selfdisclosure and liking: A meta-analytic review. Psychological Bulletin, 116, 457-475.

56. Cooper, H. M. (1979). Statistically combining independent studies: A meta-analysis of sex differences in conformity research. Journal of Personality and Social Psychology, 37, 131-146.

57. Cooper, H. M., Burger, J. M., \& Good, T. L. (1981). Gender differences in the academic locus of control beliefs of young children. Journal of Personality and Social Psychology, 40, 562-572.

58. Cooper, H. M., \& Dorr, N. (1995). Race comparisons on need for achievement: A meta-analytic alternative to Graham's narrative review. Review of Educational Research, 65, 483-508.
59. Cooper, H., \& Hazelrigg, P. (1988). Personality moderators of interpersonal expectancy effects: An integrative research review. Journal of Personality and Social Psychology, 55, 937-949.

60. Crain, R. L., \& Mahard, R. E. (1983). The effect of research methodology on desegregationachievement studies: A meta-analysis. American Journal of Sociology, 88, 839-854.

61. Crawford, A. M. (1996). Stigma associated with AIDS: A meta-analysis. Journal of Applied Social Psychology, 26, 398-416.

62. Cutler, B. L., Berman, G. L., Penrod, S., \& Fisher, R. P. (1994). Conceptual, practical, and empirical issues associated with eyewitness identification test media. In D. F. Ross, J. D. Read, \& M. P. Toglia (Eds.), Adult eyewitness testimony (pp. 163-181). New York: Cambridge University Press.

63. Cutler, B. L., \& Penrod, S. D. (1989). Forensically relevant moderators of the relation between eyewitness identification accuracy and confidence. Journal of Applied Psychology, 74, 650-652.

64. Davis, M. H., \& Kraus, L. A. (1997). Personality and empathic accuracy. In W. Ickes (Ed.), Empathic accuracy (pp. 144-168). New York: Guilford. 65. DePaulo, B. M., Stone, J. I., \& Lassiter, G. D. (1985). Deceiving and detecting deceit. In B. R. Schlenker (Ed.), The self and social life (pp. 323370). New York: McGraw-Hill.

66. DePaulo, B. M. \& Rosenthal, R. (1980). Modality effects in the detection of deception. Review of Personality and Social Psychology, 1, 125-162.

67. DePaulo, B. M., Zuckerman, M., \& Rosenthal, R. (1980). Humans as lie detectors. Journal of Communication, 30, 129-139.

68. DeVader, C. L., Bateson, A. G., \& Lord, R. G. (1986). Attribution theory: A meta-analysis of attributional hypotheses. In E. A. Locke (Ed.), Generalizing from laboratory to field settings (pp. 6379). Lexington, MA: D. C. Heath.

69. Dillard, J. P., Hunter, J. E., \& Burgoon, M. (1984). Sequential-request persuasive strategies: Meta-analysis of foot-in-the-door and door-in-the-face. Human Communication Research, 10, 461-488.

70. Dindia, K., \& Allen, M. (1992). Sex differences in self-disclosure: A meta-analysis. Psychological Bulletin, 112, 106-124.

71. Dobbins, G. H., \& Platz, S. J. (1986). Sex differences in leadership: How real are they? Academy of Management Review, 11, 118-127.

72. Donahue, M. J. (1986). Intrinsic and extrinsic religiousness: Review and meta-analysis. Journal of Personality and Social Psychology, 48, 400-419. 73. Driskell, J. E., \& Mullen, B. (1990). Status, 
expectations, and behavior: A meta-analytic review and test of the theory. Personality and Social Psychology Bulletin, 16, 541-553.

74. Druckman, D. (1994). Determinants of compromising behavior in negotiation: A meta-analysis. Journal of Conflict Resolution, 38, 507-556.

75. Dusek, J. B., \& Joseph, G. (1983). The bases of teacher expectancies: A meta-analysis. Journal of Educational Psychology, 75, 327-346.

76. Eagly, A. H., Karau, S. J., Miner, J. B., \& Johnson, B. T. (1994). Gender and motivation to manage in hierarchic organizations: A meta-analysis. Leadership Quarterly, 5, 135-159.

77. Eagly, A. H., Ashmore, R. D., Makhijani, M. G., \& Longo, L. C. (1991). What is beautiful is good, but ... : A meta-analysis of research on the physical attractiveness stereotype. Psychological Bulletin, 110, 109-128.

78. Eagly, A. H., \& Carli, L. L. (1981). Sex of researchers and sex-typed communications as determinants of sex differences in influenceability: A meta-analysis of social influence studies. Psychological Bulletin, 90, 1-20.

79. Eagly, A. H., \& Crowley, M. (1986). Gender and helping behavior: A meta-analytic review of the social psychological literature. Psychological Bulletin, 100, 283-308.

80. Eagly, A. H., \& Johnson, B. T. (1990). Gender and leadership style: A meta-analysis. Psychological Bulletin, 108, 233-256.

81. Eagly, A. H., \& Karau, S. J. (1991). Gender and the emergence of leaders: A meta-analysis. Journal of Personality and Social Psychology, 60, 685-710.

82. Eagly, A. H., Karau, S. J., \& Johnson, B. T. (1992). Gender and leadership style among school principals: A meta-analysis. Educational Administration Quarterly, 28, 76-102.

83. Eagly, A. H., Karau, S. J., \& Makhijani, M. G. (1995). Gender and the effectiveness of leaders: A meta-analysis. Psychological Bulletin, 117, 125-145.

84. Eagly, A. H., Makhijani, M. G., \& Klonsky, B. G. (1992). Gender and the evaluation of leaders: A meta-analysis. Psychological Bulletin, 111, 3-22.

85. Eagly, A. H., \& Steffen, V. J. (1986). Gender and aggressive behavior: A meta-analytic review of the social psychological literature. Psychological Bulletin, 100, 309-330.

86. Eisenberg, N., \& Lennon, R. (1983). Sex differences in empathy and related capacities. Psychological Bulletin, 94, 100-131.

87. Eisenberg, N., \& Miller, P. A. (1987). The relation of empathy to prosocial and related behaviors. Psychological Bulletin, 101, 91-119.

88. Erel, O., \& Burman, B. (1995). Interrelatedness of marital relations and parent-child relations: A meta-analytic review. Psychological Bulletin, 118, $108-132$.
89. Evans, C. R., \& Dion, K. L. (1991). Group cohesion and performance: A meta-analysis. Small Group Research, 22, 175-186.

90. Falbo, T., \& Polit, D. F. (1986). Quantitative review of the only child literature: Research evidence and theory development. Psychological Bulletin, 100, 176-189.

91. Farley, J. U., Lehmann, D. R., \& Ryan, M. J. (1981). Generalizing from "imperfect" replication. Journal of Business, 54, 597-610.

92. Feingold, A. (1988). Matching for attractiveness in romantic partners and same-sex friends: A metaanalysis and theoretical critique. Psychological Bulletin, 104, 226-235.

93. Feingold, A. (1990). Gender differences in effects of physical attractiveness on romantic attraction: A comparison across five research paradigms. Journal of Personality and Social Psychology, 59, 981993.

94. Feingold, A. (1991). Sex differences in the effects of similarity and physical attractiveness on opposite-sex attraction. Basic and Applied Social Psychology, 12, 357-367.

95. Feingold, A. (1992). Gender differences in mate selection preferences: A test of the parental investment model. Psychological Bulletin, 112, 125-139.

96. Feingold, A. (1992). Good-looking people are not what we think. Psychological Bulletin, 111, 304341.

97. Feingold, A. (1994). Gender differences in personality: A meta-analysis. Psychological Bulletin, 116, 429-456.

98. Ferguson, E. (1996). Predictors of future behaviour: A review of the psychological literature on blood donation. British Journal of Health Psychology, 1, 287-309.

99. Fern, E. F., Monroe, K. B., \& Avila, R. A. (1986). Effectiveness of multiple request strategies: A synthesis of research results. Journal of Marketing Research, 23, 144-152.

100. Fiedler, F. E. (1964). A contingency model of leadership effectiveness. Advances in Experimental Social Psychology, 1, 149-190.

101. Findley, M. J., \& Cooper, H. M. (1983). Locus of control and academic achievement: A literature review. Journal of Personality and Social Psychology, 44, 419-427.

102. Finkelstein, L. M., Burke, M. J., \& Raju, M. S. (1995). Age discrimination in simulated employment contexts: An integrative analysis. Journal of Applied Psychology, 80, 652-663.

103. Ford, J. K., Kraiger, K., \& Schechtman, S. L. (1986). Study of race effects in objective indices and subjective evaluations of performance: A meta-analysis of performance criteria. Psychological Bulletin, 99, 330-337.

104. Fox, R. J., Crask, M. R., \& Kim, J. (1988). Mail survey response rate: A meta-analysis of selected 
techniques for inducing response. Public Opinion Quarterly, 52, 467-491.

105. Frieze, I. H., Whitley, B. E., Jr., Hanusa, B. H., \& McHugh, M. C. (1982). Assessing the theoretical models for sex differences in causal attributions for success and failure. Sex Roles, 8, 333-343.

106. Fuchs, D., \& Fuchs, L. S. (1986). Test procedure bias: A meta-analysis of examiner familiarity effects. Review of Educational Research, 56, 243-262.

107. Fuller, J. B., Patterson, C. E. P., Hester, K., \& Stringer, D. Y. (1996). A quantitative review of research on charismatic leadership. Psychological Reports, 78, 271-287.

108. Funder, D. C., \& Harris, M. J. (1986). Experimental effects and person effects in delay of gratification. American Psychologist, 41, 476-477.

109. Fyock, J., \& Stangor, C. (1994). The role of memory biases in stereotype maintenance. British Journal of Social Psychology, 33, 331-343.

110. Gastil, J. (1994). A meta-analytic review of the productivity and satisfaction of democratic and autocratic leadership. Small Group Research, 25, $384-410$.

111. Gerstner, C. R., \& Day, D. V. (1997). Metaanalytic review of leader-member exchange theory: Correlates and construct issues. Journal of Applied Psychology, 82, 827-844.

112. Gladstone, T. R. G., \& Kaslow, N. J. (1995). Depression and attributions in children and adolescents: A meta-analytic review. Journal of Abnormal Child Psychology, 23, 597-606.

113. Glynn, C. J., Hayes, A. F., \& Shanahan, J. (1997). Perceived support for one's opinions and willingness to speak out: A meta-analysis of survey studies on the "spiral of silence." Public Opinion Quarterly, 61, 452-463.

114. Gordon, R. A. (1996). Impact of ingratiation on judgments and evaluations: A meta-analytic investigation. Journal of Personality and Social Psychology, 71, 54-70.

115. Gorey, K. M., \& Cryns, A. G. (1995). Lack of racial differences in behavior: A quantitative replication of Rushton's (1988) review and an independent meta-analysis. Personality and Individual Differences, 19, 345-353.

116. Graen, G., Alvares, K., Orris, J. B., \& Martella, J. A. (1970). Contingency model of leadership effectiveness: Antecedent and evidential results. Psychological Bulletin, 74, 285-296.

117. Grewal, D., Kavanoor, S., Fern, E. F., Costley, C., \& Barnes, J. (1997). Comparative versus noncomparative advertising: A meta-analysis. Journal of Marketing, 61, 1-15.

118. Gross, S. R., \& Miller, N. (1997). The "Golden
Section" and bias in perceptions of social consensus. Personality and Social Psychology Review, 1, 241-271.

119. Gully, S. M., Devine, D. J., \& Whitney, D. J. (1995). A meta-analysis of cohesion and performance: Effects of levels of analysis and task interdependence. Small Group Research, 26, 497-520.

120. Halberstadt, A. G. (1983). Family expressiveness styles and nonverbal communication skills. Journal of Nonverbal Behavior, 8, 14-26.

121. Hall, G. C. N., Shondrick, D. D., \& Hirschman, R. (1993). The role of sexual arousal in sexually aggressive behavior: A meta-analysis. Journal of Consulting and Clinical Psychology, 61, 1091-1095.

122. Hall, J. A. (1978). Gender effects in decoding nonverbal cues. Psychological Bulletin, 85, 185-193.

123. Hall, J. A. (1984). Nonverbal sex differences: Communication accuracy and expressive style. Baltimore: Johns Hopkins.

124. Hall, J. A., \& Briton, N. J. (1993). Gender, nonverbal behavior, and expectations. In P. D. Blanck (Ed.), Interpersonal expectations: Theory, research, and applications (pp. 276-295). New York: Cambridge University Press.

125. Hall, J. A., \& Halberstadt, A. G. (1986). Smiling and gazing. In J. S. Hyde \& M. C. Linn (Eds.), The psychology of gender: Advances through metaanalysis (pp. 136-158). Baltimore: Johns Hopkins University Press.

126. Hall, J. A., Halberstadt, A. G., \& O’Brien, C. E. (1997). "Subordination" and nonverbal sensitivity: A study and synthesis of findings based on trait measures. Sex Roles, 37, 295-317.

127. Haring, M. J., Stock, W. A., \& Okun, M. A. (1984). A research synthesis of gender and social class as correlates of subjective well-being. Human Relations, 37, 645-657.

128. Haring-Hidore, M., Stock, W. A., Okun, M. A., \& Witter, R. A. (1985). Marital status and subjective well-being: A research synthesis. Journal of Marriage and the Family, 47, 947-953.

129. Harris, M. J., \& Rosenthal, R. (1985). Mediation of interpersonal expectancy effects: 31 meta-analyses. Psychological Bulletin, 97, 363-386.

130. Harris, M. J., \& Rosenthal, R. (1986). Four factors in the mediation of teacher expectancy effects. In R. S. Feldman (Ed.), The social psychology of education: Current theory and research (pp. 91-114). New York: Cambridge University Press.

131. Harris, M. M., \& Schaubroeck, J. (1988). A meta-analysis of self-supervisor, self-peer, and peer-supervisor ratings. Personnel Psychology, 41, 43-62. 
132. Hattie, J. (1992). Self-concept. Hillsdale, NJ: Erlbaum.

133. Hausenblas, H. A., Carron, A. V., \& Mack, D. E. (1997). Application of the theories of reasoned action and planned behavior to exercise: A meta-analysis. Journal of Sport \& Exercise Psychology, 19, 36-51.

134. Hearold, S. (1986). A synthesis of 1043 effects of television on social behavior. In G. Comstock (Ed.), Public communication and behavior (Vol. 1, pp. 65-133). Orlando, FL: Academic Press.

135. Herrett-Skjellum, J., \& Allen, M. (1996). Television programming and sex stereotyping: A metaanalysis. Communication Yearbook, 19, 157-185.

136. Hines, J. M., Hungerford, H. R., \& Tomera, A. N. (1987). Analysis and synthesis of research on responsible environmental behavior: A meta-analysis. Journal of Environmental Education, 18, 1-8.

137. Hopkins, K. D., \& Gullickson, A. R. (1992). Response rates in survey research: A meta-analysis of the effects of monetary gratuities. Journal of Experimental Education, 61, 52-62.

138. Hornik, J., Cherian, J., Madansky, M., \& Narayana, C. (1995). Determinants of recycling behavior: A synthesis of research results. Journal of Socio-Economics, 24, 105-127.

139. Hox, J. J., \& De Leeuw, E. D. (1994). A comparison of nonresponse in mail, telephone, and faceto-face surveys: Applying multilevel modeling to meta-analysis. Quality \& Quantity, 28, 329-344.

140. Hull, J. G., \& Bond, C. F., Jr. (1986). Social and behavioral consequences of alcohol consumption and expectancy: A meta-analysis. Psychological Bulletin, 99, 347-360.

141. Hyde, J. S. (1984). How large are gender differences in aggression? A developmental metaanalysis. Developmental Psychology, 20, 722-736.

142. Isenberg, D. J. (1986). Group polarization: A critical review and meta-analysis. Journal of Personality and Social Psychology, 50, 1141-1151.

143. Ito, T. A., Miller, N., \& Pollock, V. E. (1996). Alcohol and aggression: A meta-analysis on the moderating effects of inhibitory cues, triggering events, and self-focused attention. Psychological Bulletin, 120, 60-82.

144. Jackson, L. A., Hunter, J. E., \& Hodge, C. N. (1995). Physical attractiveness and intellectual competence: A meta-analytic review. Social Psychology Quarterly, 58, 108-122.

145. Johnson, B. T., \& Eagly, A. H. (1989). Effects of involvement on persuasion: A meta-analysis. Psychological Bulletin, 106, 290-314.

146. Johnson, C., \& Mullen, B. (1993). The determinants of differential group evaluations in distinctiveness-based illusory correlations in stereotyping. British Journal of Social Psychology, 32, 253-263.

147. Joiner, T. E., Jr., \& Wagner, K. D. (1995). Attributional style and depression in children and adolescents: A meta-analytic review. Clinical Psychology Review, 15, 777-798.

148. Kalechstein, A. D., \& Nowicki, S., Jr. (1997). A meta-analytic examination of the relationship between control expectancies and academic achievement: An 11-year follow-up to Findley and Cooper. Genetic, Social, and General Psychology Monographs, 123, 27-56.

149. Karau, S. J., \& Williams, K. D. (1993). Social loafing: A meta-analytic review and theoretical integration. Journal of Personality and Social Psychology, 65, 681-706.

150. Karney, B. R., \& Bradbury, T. N. (1995). The longitudinal course of marital quality and stability: A review of theory, method, and research. Psychological Bulletin, 118, 3-34.

151. Kenny, D. A. (1994). Interpersonal perception: A social relations analysis. New York: Guilford Press.

152. Kenny, D. A., \& DePaulo, B. M. (1993). Do people know how others view them? An empirical and theoretical account. Psychological Bulletin, $114,145-161$.

153. Kim, M., \& Hunter, J. E. (1993). Attitudebehavior relations: A meta-analysis of attitudinal relevance and topic. Journal of Communication, 43, 101-142.

154. Kim, M., \& Hunter, J. E. (1993). Relationships among attitudes, behavioral intentions, and behavior: A meta-analysis of past research, part 2. Communication Research, 20, 331-364.

155. Kite, M. E. (1984). Sex differences in attitudes toward homosexuals: A meta-analytic review. Journal of Homosexuality, 10, 69-81.

156. Kite, M. E., \& Johnson, B. T. (1988). Attitudes toward older and younger adults: A meta-analysis. Psychology and Aging, 3, 233-244.

157. Kite, M. E., \& Whitley, B. E., Jr. (1996). Sex differences in attitudes toward homosexual persons, behaviors, and civil rights: A meta-analysis. Personality and Social Psychology Bulletin, 22, 336-353.

158. Knight, G. P., Fabes, R. A., \& Higgins, D. A. (1996). Concerns about drawing causal inferences from meta-analyses: An example in the study of gender differences in aggression. Psychological Bulletin, 119, 410-421.

159. Koelega, H. S. (1992). Extraversion and vigilance performance: 30 years of inconsistencies. Psychological Bulletin, 112, 239-258.

160. Kraiger, K., \& Ford, J. K. (1985). A metaanalysis of ratee race effects in performance ratings. Journal of Applied Psychology, 70, 56-65.

161. Kraiger, K., \& Ford, J. K. (1990). The relation of job knowledge, job performance, and supervisory ratings as a function of ratee race. Human Performance, 3, 269-279. 
162. Kraus, S. J. (1995). Attitudes and the prediction of behavior: A meta-analysis of the empirical literature. Personality and Social Psychology Bulletin, 21, 58-75.

163. Kunda, Z., \& Thagard, P. (1996). Forming impressions from stereotypes, traits, and behaviors: A parallel-constraint-satisfaction theory. Psychological Review, 103, 284-308.

164. Larsen, R. J., \& Sinnett, L. M. (1991). Metaanalysis of experimental manipulations: Some factors affecting the Velten mood induction procedure. Personality and Social Psychology Bulletin, 17, 323-334.

165. Lord, R. G., De Vader, C. L., \& Alliger, G. M. (1986). A meta-analysis of the relation between personality traits and leadership perceptions: An application of validity generalization procedures. Journal of Applied Psychology, 71, 402-410.

166. Lowe, K. B., Kroeck, K. G., Sivasubramaniam, N. (1996). Effectiveness correlates of transformation and transactional leadership: A meta-analytic review of the MLQ literature. Leadership Quarterly, 7, 385-425.

167. Lustig, M. W., \& Andersen, P. A. (1990). Generalizing about communication apprehension and avoidance: Multiple replications and meta-analyses. Journal of Social Behavior and Personality, 5, 309-340.

168. Lynn, M. (1991). Scarcity effects on value: A quantitative review of the commodity theory literature. Psychology \& Marketing, 8, 43-57.

169. Lytton, H., \& Romney, D. M. (1991). Parents' differential socialization of boys and girls: A metaanalysis. Psychological Bulletin, 109, 267-296.

170. Mabe, P. A., III., \& West, S. G. (1982). Validity of self-evaluation of ability: A review and metaanalysis. Journal of Applied Psychology, 67, 280296.

171. MacCoun, R. J., \& Kerr, N. L. (1988). Asymmetric influence in mock jury deliberation: Jurors' bias for leniency. Journal of Personality and Social Psychology, 54, 21-33.

172. Mann, R. D. (1959). A review of the relationships between personality and performance in small groups. Psychological Bulletin, 56, 241-270.

173. Matsumoto, D. (1987). The role of facial response in the experience of emotion: More methodological problems and a meta-analysis. Journal of Personality and Social Psychology, 52, 769774.

174. Matt, G. E., Vazquez, C., \& Campbell, W. K. (1992). Mood-congruent recall of affectively toned stimuli: A meta-analytic review. Clinical Psychology Review, 12, 227-255.
175. Mazzella, R., \& Feingold, A. (1994). The effects of physical attractiveness, race, socioeconomic status, and gender of defendants and victims on judgments of mock jurors: A meta-analysis. Journal of Applied Social Psychology, 24, 1315-1344.

176. Miles, D. R., \& Carey, G. (1997). Genetic and environmental architecture of human aggression. Journal of Personality and Social Psychology, 72, 207-217.

177. Miller, B., \& Cafasso, L. (1992). Gender differences in caregiving: Fact or artifact? The Gerontologist, 32, 498-507.

178. Miller, P. A., \& Eisenberg, N. (1988). The relation of empathy to aggressive and externalizing/antisocial behavior. Psychological Bulletin, 103, 324-344.

179. Morgan, M., \& Shanahan, J. (1997). Two decades of cultivation research: An appraisal and meta-analysis. Communication Yearbook, 20, $1-45$.

180. Mudrack, P. E. (1990). Machiavellianism and locus of control: A meta-analytic review. The Journal of Social Psychology, 130, 125-126.

181. Mullen, B. (1985). Strength and immediacy of sources: A meta-analytic evaluation of the forgotten elements of social impact theory. Journal of Personality and Social Psychology, 48, 1458-1466.

182. Mullen, B. (1991). Group composition, salience, and cognitive representations: The phenomenology of being in a group. Journal of Experimental Social Psychology, 27, 297-323.

183. Mullen, B., Anthony, T., Salas, E., \& Driskell, J. E. (1994). Group cohesiveness and quality of decision making: An integration of tests of the groupthink hypothesis. Small Group Research, 25, 189-204.

184. Mullen, B., Atkins, J. L., Champion, D. S., Edwards, C., Hardy, D., Story, J. E., \& Vanderklok, M. (1985). The false consensus effect: A meta-analysis of 115 hypothesis tests. Journal of Experimental Social Psychology, 21, 262-283.

185. Mullen, B., Symons, C., Hu, L., \& Salas, E. (1989). Group size, leadership behavior, and subordinate satisfaction. The Journal of General Psychology, 116, 155-169.

186. Mullen, B., Johnson, C., \& Salas, E. (1991). Effects of communication network structure: Components of positional centrality. Social Networks, 13, 169-186.

187. Mullen, B., Copper, C., Cox, P., Fraser, C., Hu, L., Meisler, A., Smith, C., \& Symons, C. (1991). Boundaries around group interaction: A meta-analytic integration of the effects of group 
size. The Journal of Social Psychology, 131, 271-283.

188. Mullen, B., Brown, R., \& Smith, C. (1992). Ingroup bias as a function of salience, relevance, and status: An integration. European Journal of Social Psychology, 22, 103-122.

189. Mullen, B., Bryant, B., \& Driskell, J. E. (1997). Presence of others and arousal: An integration. Group Dynamics: Theory, Research, and Practice, 1, 52-64.

190. Mullen, B., \& Copper, C. (1994). The relation between group cohesiveness and performance: An integration. Psychological Bulletin, 115, 210-227.

191. Mullen, B., Cooper, C., \& Driskell, J. E. (1990). Jaywalking as a function of model behavior. Personality and Social Psychology Bulletin, 16, 320330.

192. Mullen, B., \& Felleman, V. (1990). Tripling in the dorms: A meta-analytic integration. Basic and Applied Social Psychology, 11, 33-43.

193. Mullen, B., \& Hu, L. (1988). Social projection as a function of cognitive mechanisms: Two metaanalytic integrations. British Journal of Social Psychology, 27, 333-356.

194. Mullen, B., \& Hu, L. (1989). Perceptions of ingroup and outgroup variability: A meta-analytic integration. Basic and Applied Social Psychology, 10, 233-252.

195. Mullen, B., \& Johnson, C. (1990). Distinctiveness-based illusory correlations and stereotyping: A meta-analytic integration. British Journal of Social Psychology, 29, 11-28.

196. Mullen, B., Johnson, C., Salas, E. (1991). Productivity loss in brainstorming groups: A metaanalytic integration. Basic and Applied Social Psychology, 12, 3-23.

197. Mullen, B., \& Riordan, C. A. (1988). Selfserving attributions for performance in naturalistic settings: A meta-analytic review. Journal of Applied Social Psychology, 18, 3-22.

198. Mullen, B., Salas, E., \& Driskell, J. E. (1989). Salience, motivation, and artifact as contributions to the relation between participation rate and leadership. Journal of Experimental Social Psychology, 25, 545-559.

199. Multon, K. D., Brown, S. D., \& Lent, R. W. (1991). Relation of self-efficacy beliefs to academic outcomes: A meta-analytic investigation. Journal of Counseling Psychology, 38, 30-38.

200. Murnen, S. K., \& Stockton, M. (1997). Gender and self-reported sexual arousal in response to sexual stimuli: A meta-analytic review. Sex Roles, 37, 135-153.

201. Murphy, K. R., \& Balzer, W. K. (1989). Rater errors and rating accuracy. Journal of Applied Psychology, 74, 619-624.

202. Narby, D. J., Cutler, B. L., \& Moran, G. (1993). A meta-analysis of the association between au- thoritarianism and jurors' perceptions of defendant culpability. Journal of Applied Psychology, 78, $34-42$.

203. Newcomb, A. F., Bukowski, W. M., \& Pattee, L. (1993). Children's peer relations: A meta-analytic review of popular, rejected, neglected, controversial, and average sociometric status. Psychological Bulletin, 113, 99-128.

204. Newcomb, A. F., \& Bagwell, C. L. (1995). Children's friendship relations: A meta-analytic review. Psychological Bulletin, 117, 306-347.

205. Ochoa, S. H., \& Olivarez, A., Jr. (1995). A meta-analysis of peer rating sociometric studies of pupils with learning disabilities. The Journal of Special Education, 29, 1-19.

206. O'Connor, W. E., Morrison, T. G., McLeod, L. D., \& Anderson, D. (1996). A meta-analytic review of the relationship between gender and belief in a just world. Journal of Social Behavior and Personality, 11, 141-148.

207. O'Keefe, D. J. (1987). The persuasive effects of delaying identification of high- and low-credibility communicators: A meta-analytic review. Central States Speech Journal, 38, 63-72.

208. O'Keefe, D. J., \& Figgé, M. (1997). A guiltbased explanation of the door-in-the-face influence strategy. Human Communication Research, 24, 64-81.

209. Okun, M. A., Stock, W. A., Haring, M. J., \& Witter, R. A. (1984). The activity/subjective wellbeing relation: A quantitative synthesis. Research on Aging, 6, 45-65.

210. Okun, M. A., \& Stock, W. A. (1987). The construct validity of subjective well-being measures: An assessment via quantitative research syntheses. Journal of Community Psychology, 15, 481-492.

211. O’Leary-Kelley, A. M., Martocchio, J. J., \& Frink, D. D. (1994). A review of the influence of group goals on group performance. Academy of Management Journal, 37, 1285-1301.

212. Olian, J. D., Schwab, D. P., \& Haberfeld, Y. (1988). The impact of applicant gender compared to qualifications on hiring recommendations: A meta-analysis of experimental studies. Organizational Behavior and Human Decision Processes, 41, 180-195.

213. Oliver, M. B., \& Hyde, J. S. (1993). Gender differences in sexuality: A meta-analysis. Psychological Bulletin, 114, 29-51.

214. Olweus, D. (1979). Stability of aggressive reaction patterns in males: A review. Psychological Bulletin, 86, 852-875.

215. Olweus, D. (1984). Stability in aggressive and withdrawn, inhibited behavior patterns. In R. M. Kaplan, V. J. Konecni, \& R. W. Novaco (Eds.), Aggression in children and youth (pp. 104-137). The Hague: Martinus Nijhoff. 
216. Paik, H., \& Comstock, G. (1994). The effects of television violence on antisocial behavior: A metaanalysis. Communication Research, 21, 516-546.

217. Patterson, M. L., \& Ritts, V. (1997). Social and communicative anxiety: A review and meta-analysis. Communication Yearbook, 20, 263-303.

218. Peters, L. H., Hartke, D. D., \& Pohlmann, J. T. (1985). Fiedler's contingency theory of leadership: An application of the meta-analysis procedures of Schmidt and Hunter. Psychological Bulletin, 97, 274-285.

219. Pierce, C. A. (1996). Body height and romantic attraction: A meta-analytic test of the male-taller norm. Social Behavior and Personality, 24, 143150 .

220. Polit, D. F., \& Falbo, T. (1987). Only children and personality development: A quantitative review. Journal of Marriage and the Family, 49, 309-325.

221. Preiss, R. W., Wheeless, L. R., \& Allen, M. (1990). Potential cognitive processes and consequences of receiver apprehension: A meta-analytic review. Journal of Social Behavior and Personality, 5, 155-172.

222. Presson, P. K., \& Benassi, V. A. (1996). Illusion of control: A meta-analytic review. Journal of Social Behavior and Personality, 11, 493-510.

223. Presson, P. K., \& Benassi, V. A. (1996). Locus of control orientation and depressive symptomatology: A meta-analysis. Journal of Social Behavior and Personality, 11, 201-212.

224. Procidano, M. E. (1992). The nature of perceived social support: Findings of meta-analytic studies. Advances in Personality Assessment, 9, $1-26$.

225. Randall, D. M., \& Wolff, J. A. (1994). The time interval in the intention-behavior relationship: Meta-analysis. British Journal of Social Psychology, 33, 405-418.

226. Raudenbush, S. W. (1984). Magnitude of teacher expectancy effects on pupil IQ as a function of the credibility of expectancy induction: A synthesis of findings from 18 experiments. Journal of Educational Psychology, 76, 85-97.

227. Rhodes, N., \& Wood, W. (1992). Self-esteem and intelligence affect influenceability: The mediating role of message reception. Psychological Bulletin, 111, 156-171.

228. Ritts, V., Patterson, M. L., \& Tubbs, M. E. (1992). Expectations, impressions, and judgments of physically attractive students. Review of Educational Research, 62, 413-426.

229. Roberts, J. V. (1985). The attitude-memory relationship after 40 years: A meta-analysis of the literature. Basic and Applied Social Psychology, 6, 221-241.

230. Roese, N. J., \& Jamieson, D. (1993). Twenty years of bogus pipeline research: A critical review and meta-analysis. Psychological Bulletin, 114, 363-375.

231. Rojahn, K., \& Pettigrew, T. F. (1992). Memory for schema-relevant information: A meta-analytic resolution. British Journal of Social Psychology, 31, 81-109.

232. Rosenthal, R. (1968). Experimenter expectancy and the reassuring nature of the null hypothesis decision procedure. Psychological Bulletin Monograph, 70, 30-47.

233. Rosenthal, R. (1969). Interpersonal expectations: Effects of the experimenter's hypothesis. In R. Rosenthal \& R. L. Rosnow (Eds.), Artifact in behavioral research (pp. 181-277). New York: Academic Press.

234. Rosenthal, R., \& DePaulo, B. M. (1979). Sex differences in accommodation in nonverbal communication. In R. Rosenthal (Ed.), Skill in nonverbal communication: Individual differences (pp. 68-103). Cambridge: Oelgeschlager, Gunn \& Hain.

235. Rosenthal, R., \& Rosnow, R. L. (1975). The volunteer subject. New York: Wiley.

236. Rosenthal, R., \& Rubin, D. B. (1978). Interpersonal expectancy effects: The first 345 studies. The Behavioral and Brain Sciences, 3, 377-386.

237. Rummel, A., \& Feinberg, R. (1988). Cognitive evaluation theory: A meta-analytic review of the literature. Social Behavior and Personality, 16, 147-164.

238. Russell, J. A. (1994). Is there universal recognition of emotion from facial expression? A review of the cross-cultural studies. Psychological Bulletin, 115, 102-141.

239. Sackett, P. R., \& DuBois, C. L. (1991). Raterratee race effects on performance evaluation. Journal of Applied Psychology, 76, 873-877.

240. Saks, M. J., \& Marti, M. W. (1997). A metaanalysis of the effects of jury size. Law and Human Behavior, 21, 451-467.

241. Sally, D. (1995). Conversation and cooperation in social dilemmas. Rationality and Society, 7, 58-92.

242. Saragovi, C., Koestner, R., Dio, L. D., \& Aubé, J. (1997). Agency, communion, and wellbeing: Extending Helgeson's (1994) model. Journal of Personality and Social Psychology, 73, 593609.

243. Schimmack, U. (1996). Cultural influences on the recognition of emotion by facial expression: 
Individualistic or Caucasian cultures? Journal of Cross-Cultural Psychology, 27, 37-50.

244. Schofield, J. W., \& Whitley, B. E., Jr. (1983). Peer nomination vs. rating scale measurement of children's peer preferences. Social Psychology Quarterly, 46, 242-251.

245. Schriesheim, C. A., Tepper, B. J., \& Tetrault, L. A. (1994). Least preferred co-worker score, situational control, and leadership effectiveness: A meta-analysis of contingency model performance predictions. Journal of Applied Psychology, 79, 561-573.

246. Schuerger, J. M., Zarrella, K. L., \& Hotz, A. S. (1989). Factors that influence the temporal stability of personality by questionnaire. Journal of Personality and Social Psychology, 56, 777-783.

247. Schultz, P. W., \& Oskamp, S. (1996). Effort as a moderator of the attitude-behavior relationship: General environmental concern and recycling. Social Psychology Quarterly, 59, 375-383.

248. Schutte, J. W., \& Hosch, H. M. (1997). Gender differences in sexual assault verdicts: A meta-analysis. Journal of Social Behavior and Personality, 12, 759-772.

249. Schütz, H., \& Six, B. (1996). How strong is the relationship between prejudice and discrimination? A meta-analytic answer. International Journal of Intercultural Relations, 20, 441-462.

250. Schwarzer, R., \& Leppin, A. (1989). Social support and health: A meta-analysis. Psychology and Health, 3, 1-15.

251. Schwarzer, R., \& Leppin, A. (1991). Social support and health: A theoretical and empirical overview. Journal of Social and Personal Relationships, 8, 99-127.

252. Sedikides, C., \& Ostrom, T. M. (1988). Are person categories used when organizing information about unfamiliar sets of persons? Social Cognition, 6, 252-267.

253. Segrin, C., \& Dillard, J. P. (1992). The interactional theory of depression: A meta-analysis of the research literature. Journal of Social and Clinical Psychology, 11, 43-70.

254. Shapiro, P. N., \& Penrod, S. (1986). Metaanalysis of facial identification studies. Psychological Bulletin, 100, 139-156.

255. Sheppard, B. H., Hartwick, J., \& Warshaw, P. R. (1988). The theory of reasoned action: A metaanalysis of past research with recommendations for modifications and future research. Journal of Consumer Research, 15, 325-343.

256. Singer, E., Von Thurn, D. R., \& Miller, E. R. (1995). Confidentiality assurances and response: A quantitative review of the experimental literature. Public Opinion Quarterly, 77, 59-66.

257. Skinner, M., \& Mullen, B. (1991). Facial asymmetry in emotional expression: A meta-analysis of research. British Journal of Social Psychology, 30, 113-124.

258. Smith, C. E., Fernengel, K., Holcroft, C., Gerald, K., \& Marien, L. (1994). Meta-analysis of the associations between social support and health outcomes. Annals of Behavioral Medicine, 16, 352362.

259. Smith, M. L. (1980). Sex bias in counseling and psychotherapy. Psychological Bulletin, 87, 392-407.

260. Sohn, D. (1982). Sex differences in achievement self-attributions: An effect-size analysis. Sex Roles, 8, 345-357.

261. Spangler, W. D. (1992). Validity of questionnaire and TAT measures of need for achievement: Two meta-analyses. Psychological Bulletin, 112, 140-154.

262. Sporer, S. L., Penrod, S., Read, D., \& Cutler, B. (1995). Choosing, confidence, and accuracy: A meta-analysis of the confidence-accuracy relation in eyewitness identification studies. Psychological Bulletin, 118, 315-327.

263. Stangor, C., \& McMillan, D. (1992). Memory for expectancy-congruent and expectancy-incongruent information: A review of the social and social developmental literatures. Psychological Bulletin, 111, 42-61.

264. Steblay, N. M. (1987). Helping behavior in rural and urban environments: A meta-analysis. Psychological Bulletin, 102, 346-356.

265. Steblay, N. M. (1992). A meta-analytic review of the weapon focus effect. Law and Human Behavior, 16, 413-424.

266. Steblay, N. M. (1997). Social influence in eyewitness recall: A meta-analytic review of lineup instruction effects. Law and Human Behavior, 21, 283-297.

267. Steele, C. M., \& Southwick, L. (1985). Alcohol and social behavior I: The psychology of drunken excess. Journal of Personality and Social Psychology, 48, 18-34.

268. Stein, R. T., \& Heller, T. (1979). An empirical analysis of the correlations between leadership status and participation rates reported in the literature. Journal of Personality and Social Psychology, 37, 1993-2002.

269. Stevenson, M. R., \& Black, K. N. (1988). Paternal absence and sex-role development: A metaanalysis. Child Development, 59, 793-814.

270. Stier, D. S., \& Hall, J. A. (1984). Gender differences in touch: An empirical and theoretical review. Journal of Personality and Social Psychology, 47, 440-459.

271. Stiff, J. B. (1986). Cognitive processing of persuasive message cues: A meta-analytic review of the effects of supporting information on attitudes. Communication Monographs, 53, 75-89.

272. Stock, W. A., Okun, M. A., Haring, M. J., \& Witter, R. A. (1985). Race and subjective well- 
being in adulthood: A black-white research synthesis. Human Development, 28, 192-197.

273. Stogdill, R. M. (1948). Personal factors associated with leadership: A survey of the literature. The Journal of Psychology, 25, 35-71.

274. Strube, M. J. (1981). Meta-analysis and crosscultural comparison: Sex differences in child competitiveness. Journal of Cross-Cultural Psychology, 12, 3-20.

275. Strube, M. J., \& Garcia, J. E. (1981). A metaanalytic investigation of Fiedler's contingency model of leadership effectiveness. Psychological Bulletin, 90, 307-321.

276. Sugarman, D. B., \& Frankel, S. L. (1996). Patriarchal ideology and wife-assault: A meta-analytic review. Journal of Family Violence, 11, 1340.

277. Sugarman, D. B., \& Hotaling, G. T. (1997). Intimate violence and social desirability: A metaanalytic review. Journal of Interpersonal Violence, 12, 275-290.

278. Suls, J., \& Wan, C. K. (1989). The relation between type A behavior and chronic emotional distress: A meta-analysis. Journal of Personality and Social Psychology, 57, 503-512.

279. Sutton, S. R. (1982). Fear-arousing communications: A critical examination of theory and research. In J. R. Eiser (Ed.), Social psychology and behavioral medicine (pp. 303-337). New York: Wiley.

280. Sweeney, L. T., \& Haney, C. (1992). The influence of race on sentencing: A meta-analytic review of experimental studies. Behavioral Sciences and the Law, 10, 179-195.

281. Sweeney, P. D., Anderson, K., \& Bailey, S. (1986). Attributional style in depression: A metaanalytic review. Journal of Personality and Social Psychology, 50, 974-991.

282. Swim, J., Borgida, E., Maruyama, G., \& Myers, D. G. (1989). Joan McKay versus John McKay: Do gender stereotypes bias evaluations? Psychological Bulletin, 105, 409-429.

283. Swim, J. K., \& Sanna, L. J. (1996). He's skilled, she's lucky: A meta-analysis of observers' attributions for women's and men's successes and failures. Personality and Social Psychology Bulletin, 22, 507-519.

284. Symons, C. S., \& Johnson, B. T. (1997). The self-reference effect in memory: A meta-analysis. Psychological Bulletin, 121, 371-394.

285. Tanford, S., \& Penrod, S. (1984). Social influence model: A formal integration of research on majority and minority influence processes. Psychological Bulletin, 95, 189-225.
286. Tang, S., \& Hall, V. (1995). The overjustification effect: A meta-analysis. Applied Cognitive Psychology, 9, 365-404.

287. Tata, J., Anthony, T., Lin, H., Newman, B., Tang, S., Millson, M., \& Sivakumar, K. (1996). Proportionate group size and rejection of the deviate: A meta-analytic integration. Journal of Social Behavior and Personality, 11, 739-752.

288. Taylor, M. C., \& Hall, J. A. (1982). Psychological androgyny: Theories, methods, and conclusions. Psychological Bulletin, 92, 347-366.

289. Thompson, L., \& Hrebec, D. (1996). Lose-lose agreements in interdependent decision making. Psychological Bulletin, 120, 396-409.

290. Tickle-Degnen, L., \& Rosenthal, R. (1990). The nature of rapport and its nonverbal correlates. Psychological Inquiry, 1, 285-293.

291. Trappey, C. (1996). A meta-analysis of consumer choice and subliminal advertising. Psychology \& Marketing, 13, 517-530.

292. Twenge, J. M. (1997). Attitudes toward women, 1970-1995: A meta-analysis. Psychology of Women Quarterly, 21, 35-51.

293. Twenge, J. M. (1997). Changes in masculine and feminine traits over time: A meta-analysis. Sex Roles, 36, 305-325.

294. Uchino, B. N., Cacioppo, J. T., \& KiecoltGlaser, J. K. (1996). The relationship between social support and physiological processes: A review with emphasis on underlying mechanisms and implications for health. Psychological Bulletin, 119, 488-531.

295. Ucros, C. G. (1989). Mood state-dependent memory: A meta-analysis. Cognition and Emotion, 3, 139-167.

296. Underwood, B., \& Moore, B. (1982). Perspective-taking and altruism. Psychological Bulletin, 91, 143-173.

297. Vemer, E., Coleman, M., Ganong, L. H., \& Cooper, H. (1989). Marital satisfaction in remarriage: A meta-analysis. Journal of Marriage and the Family, 51, 713-725.

298. Walther, J. B., Anderson, J. F., \& Park, D. W. (1994). Interpersonal effects in computer-mediated interaction: A meta-analysis of social and antisocial communication. Communication Research, 21, 460-487.

299. Warr, P. B. (1971). Pollyanna's personal judgments. European Journal of Social Psychology, 1, 327-338.

300. Watson, D., \& Clark, L. A. (1984). Negative affectivity: The disposition to experience aversive emotional states. Psychological Bulletin, 96, 465490 . 
301. Westermann, R., Spies, K., Stahl, G., \& Hesse, F. W. (1996). Relative effectiveness and validity of mood induction procedures: A meta-analysis. European Journal of Social Psychology, 26, 557580.

302. Whatley, M. A. (1996). Victim characteristics influencing attributions of responsibility to rape victims: A meta-analysis. Aggression and Violent Behavior, 1, 81-95.

303. Whitley, B. E., Jr. (1983). Sex role orientation and self-esteem: A critical meta-analytic review. Journal of Personality and Social Psychology, 44, 765-778.

304. Whitley, B. E., Jr. (1987). The effects of discredited eyewitness testimony: A meta-analysis. The Journal of Social Psychology, 127, 209-214.

305. Whitley, B. E., Jr., \& Frieze, I. H. (1985). Children's causal attributions for success and failure in achievement settings: A meta-analysis. Journal of Educational Psychology, 77, 608-616.

306. Whitley, B. E., Jr., \& Frieze, I. H. (1986). Measuring causal attributions for success and failure: A meta-analysis of the effects of questionwording style. Basic and Applied Social Psychology, 7, 35-51.

307. Whitley, B. E., Jr., \& Kite, M. E. (1995). Sex differences in attitudes toward homosexuality: A comment on Oliver and Hyde (1993). Psychological Bulletin, 117, 146-154.

308. Whitley, B. E., Jr., McHugh, M. C., \& Frieze, I. H. (1986). Assessing the theoretical models for sex differences in causal attributions of success and failure. In J. S. Hyde \& M. C. Linn (Eds.), The psychology of gender (pp. 102-135). Baltimore: Johns Hopkins University Press.

309. Whitley, B. E., Jr., \& Schofield, J. W. (1986). A meta-analysis of research on adolescent contraceptive use. Population and Environment, 8, 173-203.

310. Wiersma, U. J. (1992). The effects of extrinsic rewards in intrinsic motivation: A meta-analysis. Journal of Occupational and Organizational Psychology, 65, 101-114.

311. Willson, V. L., \& Putnam, R. R. (1982). A meta-analysis of pretest sensitization effects in ex- perimental design. American Educational Research Journal, 19, 249-258.

312. Wilson, E. J., \& Sherrell, D. L. (1993). Source effects in communication and persuasion research: A meta-analysis of effect size. Journal of the Academy of Marketing Science, 21, 101-112.

313. Wofford, J. C., \& Liska, L. Z. (1993). Path-goal theories of leadership: A meta-analysis. Journal of Management, 19, 857-876.

314. Wood, W. (1987). Meta-analytic review of sex differences in group performance. Psychological Bulletin, 102, 53-71.

315. Wood, W., Wong, F. Y., \& Chachere, J. G. (1991). Effects of media violence on viewers' aggression in unconstrained social interaction. Psychological Bulletin, 109, 371-383.

316. Wood, W., Lundgren, S., Ouellette, J. A., Busceme, S., \& Blackstone, T. (1994). Minority influence: A meta-analytic review of social influence processes. Psychological Bulletin, 115, 323-345.

317. Wood, W., Rhodes, N., \& Whelan, M. (1989). Sex differences in positive well-being: A consideration of emotional style and marital status. Psychological Bulletin, 106, 249-264.

318. Wortman, P. M., \& Bryant, F. B. (1985). School desegregation and black achievement: An integrative review. Sociological Methods and Research, 13, 289-324.

319. Yammarino, F. J., Skinner, S. J., \& Childers, T. L. (1991). Understanding mail survey response behavior: A meta-analysis. Public Opinion Quarterly, 55, 613-639.

320. Zimmerman, R. S., \& Vernberg, D. (1994). Models of preventive health behavior: Comparison, critique, and meta-analysis. Advances in Medical Sociology, 4, 45-67.

321. Zuckerman, M., DePaulo, B. M., \& Rosenthal, R. (1981). Verbal and nonverbal communication of deception. Advances in Experimental Social Psychology, 14, 1-59.

322. Zumkley, H. (1994). The stability of aggressive behavior: A meta-analysis. German Journal of Psychology, 18, 273-281. 


\section{Appendix B}

474 Meta-Analytic Conclusions

\begin{tabular}{llllll}
\hline Meta-analytic conclusion & & \multicolumn{2}{c}{ Document } \\
nogression & $k$ & $\bar{r}$ & $S D$ & no. \\
\hline
\end{tabular}

There are genetic influences on aggressiveness

Highly aggressive men have high levels of testosterone

People become aggressive when they see aggression-related cues

People become aggressive when they are provoked

People are aggressive toward individuals who provoke them

People who have been provoked are aggressive toward bystanders

People are aggressive when they are in a bad mood

People are aggressive when they are hot

People are aggressive when they are under environmental stress

People are aggressive when they are anonymous

People who have aggressive personalities display aggressive behavior

Pornography increases aggression

Educational briefings prevent pornography from increasing aggression

Sexually aggressive men are aroused by depictions of rape

When people drink alcohol, they become aggressive

When people drink alcohol, they become aggressive

When people drink alcohol, they become aggressive

When people think they are drinking alcohol, they become aggressive

When people think they are drinking alcohol, they become aggressive

Exposure to mass media violence increases aggression

Exposure to mass media violence increases aggression

People act antisocially after seeing antisocial behavior on TV

Aggressiveness is stable over time

Males' aggressiveness is stable over time

Females' aggressiveness is stable over time

There are sex differences

Men are more aggressive than women

Men are more aggressive than women

Men are more aggressive than women

Men are more aggressive than women

After exposure to violence, men are more aggressive than women

People are more aggressive toward men than women

\begin{tabular}{|c|c|c|c|}
\hline 42 & .49 & & 176 \\
\hline 118 & .06 & .17 & 20 \\
\hline 78 & .16 & .36 & 45 \\
\hline 66 & .36 & .33 & 28 \\
\hline 143 & .51 & .26 & 47 \\
\hline 24 & .06 & .38 & 47 \\
\hline 256 & .41 & .29 & 44 \\
\hline 54 & .03 & & 13 \\
\hline 37 & .25 & .29 & 47 \\
\hline 24 & .26 & & 13 \\
\hline 27 & .18 & & 13 \\
\hline 33 & .13 & .15 & 7 \\
\hline 10 & .29 & .22 & 9 \\
\hline 18 & .24 & .10 & 121 \\
\hline 88 & .24 & .04 & 40 \\
\hline 65 & .23 & & 39 \\
\hline 49 & .26 & .32 & 143 \\
\hline 20 & .05 & & 39 \\
\hline 16 & .05 & .17 & 40 \\
\hline 1,142 & .31 & .14 & 216 \\
\hline 12 & .13 & .12 & 315 \\
\hline 528 & .12 & .40 & 134 \\
\hline 38 & .48 & .39 & 322 \\
\hline 24 & .55 & .36 & 214 \\
\hline 21 & .44 & .33 & 215 \\
\hline 110 & .31 & .23 & 158 \\
\hline 107 & .12 & .14 & 28 \\
\hline 83 & .23 & .10 & 141 \\
\hline 50 & .20 & .35 & 85 \\
\hline 20 & .11 & .16 & 27 \\
\hline 20 & .06 & .26 & 85 \\
\hline
\end{tabular}

Attitudes

Persuasive fear appeals induce attitude change

Persuasive fear appeals induce attitude change

Persuasive fear appeals induce behavior change

Persuasive fear appeals induce behavior change

Cumulative exposure to mass media influences viewers' attitudes

Mere exposure to a stimulus increases liking for that stimulus

Some people are more persuasive than others

People who are involved in a message are unlikely to be persuaded by it

A message is most persuasive if it presents a lot of information

The higher a person's credibility, the more persuasive that person will be

Good arguments are persuasive to people who have a high need to think

Sometimes a message has more persuasive impact after a delay

Information about a speaker's credibility has less impact if it is delayed

Distraction increases the persuasive impact of a message

Two-sided messages are more persuasive than one-sided messages

People are more persuaded by comparative than non-comparative ads

Subliminal advertising increases sales

$\begin{array}{rrrr}40 & .11 & .06 & 279 \\ 25 & .21 & .14 & 34 \\ 15 & .10 & .19 & 34 \\ 16 & .13 & .12 & 279 \\ 52 & .09 & .04 & 179 \\ 208 & .26 & .52 & 32 \\ 745 & .21 & & 312 \\ 40 & .10 & .17 & 145 \\ 31 & .20 & .07 & 271 \\ 10 & .10 & .04 & 271 \\ 11 & .15 & .07 & 41 \\ 20 & .00 & .43 & 11 \\ 10 & .13 & .25 & 207 \\ 104 & .03 & .17 & 37 \\ 26 & .04 & .06 & 6 \\ 95 & .11 & .21 & 117 \\ 23 & .00 & .11 & 291\end{array}$


Appendix B (continued)

\begin{tabular}{|c|c|c|c|c|}
\hline Meta-analytic conclusion & $k$ & $\bar{r}$ & $S D$ & $\begin{array}{c}\text { Document } \\
\text { no. }\end{array}$ \\
\hline \multicolumn{5}{|c|}{ Attitudes (continued) } \\
\hline Scarcity increases the value of a commodity & 49 & .12 & .16 & 168 \\
\hline There is consistency between people's attitudes and behavior & 138 & .47 & .14 & 153 \\
\hline There is consistency between people's attitudes and behavior & 92 & .65 & .14 & 154 \\
\hline There is consistency between people's attitudes and behavior & 88 & .38 & .18 & 162 \\
\hline There is consistency between people's attitudes and behavior & 37 & .45 & .46 & 91 \\
\hline There is consistency between people's attitudes and behavior & 15 & .43 & & 320 \\
\hline People do what they intend to do & 98 & .45 & .19 & 225 \\
\hline People do what they intend to do & 87 & .53 & .20 & 255 \\
\hline People do what they intend to do & 47 & .46 & .21 & 154 \\
\hline People do what they intend to do & 13 & .56 & & 320 \\
\hline \multicolumn{5}{|l|}{ People are likely to perform an action if they ... } \\
\hline intend to perform the action and believe they can control it & 17 & .51 & & 5 \\
\hline feel positively about the action and believe it is common & 87 & .66 & .13 & 255 \\
\hline \multicolumn{5}{|l|}{ People are likely to recycle if they ... } \\
\hline know about recycling & 115 & .40 & .26 & 138 \\
\hline know about recycling, like it, and have an incentive to recycle & 115 & .48 & .23 & 136 \\
\hline have concern for the environment & 7 & .11 & .12 & 247 \\
\hline
\end{tabular}

\section{Attribution}

People attribute their successes to ability

People attribute their successes to ability

People attribute their successes to effort

People attribute their successes to effort

People attribute their successes to internal factors

Students attribute their academic successes to luck

People attribute their failures to bad luck

People attribute their failures to the difficulty of their task

People attribute their failures to the difficulty of their task

People attribute their failures to external factors

People take more responsibility for success than failure

People are held more responsible for a severe than a minor accident

There are actor-observer differences in work performance attributions

Successful, expected work performances are attributed to ability

Adults who suffer depression attribute...

negative outcomes to internal, global, stable factors

positive outcomes to external, specific, unstable factors

$\begin{array}{llll}69 & .29 & .35 & 306 \\ 25 & .27 & & 305 \\ 69 & .18 & .27 & 306 \\ 25 & .14 & & 305 \\ 49 & .26 & .17 & 197 \\ 25 & .01 & & 305 \\ 69 & .10 & .43 & 306 \\ 69 & .05 & .42 & 306 \\ 25 & .22 & & 305 \\ 42 & .09 & .17 & 197 \\ 23 & .19 & .33 & 21 \\ 22 & .13 & .38 & 38 \\ 11 & .41 & .00 & 68 \\ 20 & .35 & .17 & 68 \\ & & & \end{array}$

Children who suffer depression attribute . .

negative outcomes to internal, global, stable factors

negative outcomes to internal, global, stable factors

positive outcomes to external, specific, unstable factors

positive outcomes to external, specific, unstable factors

There are sex differences

Men attribute their performance to ability

Men attribute their performance to ability

Men attribute their performance to ability

Men attribute their performance to effort

Men attribute their performance to effort

Women attribute their performance to luck

Women attribute their performance to luck

Women attribute their performance to luck

Women attribute their performance to the difficulty of their task

Women attribute their performance to the difficulty of their task 
Appendix B (continued)

\begin{tabular}{lrrr}
\hline \multicolumn{1}{c}{ Meta-analytic conclusion } & & A & $\begin{array}{c}\text { Document } \\
\text { no. }\end{array}$ \\
\hline \multicolumn{1}{c}{ Attribution (continued) } & & & $S D$ \\
& 84 & .04 & 283 \\
Women's successes are attributed to effort & 230 & .01 & 283 \\
Men's successes are attributed to ability, luck, and the ease of the task & 36 & .07 & 283 \\
Women's failures are attributed to task difficulty & 134 & .02 & 283 \\
Men's failures are attributed to lack of ability, lack of effort, and bad luck & & & \\
\hline
\end{tabular}

People behave as others expect them to behave

People behave as others expect them to behave

Expectancy effects

Males behave as others expect them to behave

Females behave as others expect them to behave

Experimenters find the research results they expect to find

Some experimenters show bigger expectancy effects than others

Some subjects show bigger experimenter expectancy effects than others

Teachers expect more from female than male students

Teachers expect more from Anglo-Americans than African-Americans

Teachers expect more from attractive than unattractive students

Teachers who have positive expectations for a student have positive interactions with that student

Teachers form self-fulfilling prophecies about students

Students achieve the most if their teachers interact with them, display warmth, and give them positive feedback

People have status expectations for one another

$\begin{array}{rrrr}114 & .16 & & 233 \\ 113 & .33 & .43 & 236 \\ 14 & .19 & & 124 \\ 28 & .08 & & 124 \\ 35 & .25 & & 232 \\ 22 & .11 & & 59 \\ 26 & .03 & & 59 \\ 28 & .07 & & 75 \\ 20 & .05 & & 75 \\ 24 & .12 & & 75 \\ 180 & .19 & & 130 \\ 165 & .19 & & 129 \\ 18 & .05 & .07 & 226 \\ 58 & .24 & & 130 \\ 50 & .26 & & 129 \\ 7 & .31 & .12 & 73\end{array}$

\section{Gender roles}

Parents encourage their children to engage in sex-stereotypic activities Exposure to TV increases acceptance of gender role stereotypes

Boys who are reared in father-absent homes are nonmasculine

Girls who are reared in father-absent homes are nonfeminine

Women are more likely than men to support the feminist movement

Members of the women's movement are perceived to be unattractive

Traditionally sex-typed people have traditional attitudes toward women

Men are recommended for jobs over women

People rate male authors more favorably than female authors

Counselors evaluate female clients more favorably than male clients

Women are more likely than men to say positive things about people

Nonmasculine men are at risk for assaulting their wives

Highly feminine women are at risk for being assaulted by their husbands

Highly feminine people...

have high self-esteem

have high self-esteem

report high social satisfaction

Highly masculine people... .

have high self-esteem

have high self-esteem

report high social satisfaction

\begin{tabular}{rlll}
21 & .21 & .11 & 169 \\
31 & .11 & .12 & 135 \\
116 & .07 & .23 & 269 \\
48 & .01 & .14 & 269 \\
46 & .39 & & 292 \\
21 & .00 & .00 & 25 \\
27 & .10 & .05 & 19 \\
19 & .20 & .16 & 212 \\
575 & .02 & .09 & 282 \\
60 & .02 & & 259 \\
6 & .21 & .35 & 299 \\
14 & .10 & .32 & 276 \\
16 & .19 & .09 & 276 \\
& & & \\
63 & .17 & .11 & 303 \\
35 & .24 & & 288 \\
23 & .27 & .12 & 242 \\
& & & \\
63 & .52 & .23 & 303 \\
36 & .52 & & 288 \\
23 & .14 & .00 & 242 \\
\hline
\end{tabular}

Group processes

Goal-setting facilitates group performance

Highly cohesive groups show high group productivity

Highly cohesive groups show high group productivity

Highly cohesive groups show high group productivity

Highly cohesive groups make bad decisions

There is social loafing when people work in a group

All-male groups outperform all-female groups

People produce more ideas alone than in group brainstorming

$\begin{array}{rrrr}26 & .42 & .08 & 211 \\ 66 & .25 & .21 & 190 \\ 51 & .17 & .17 & 119 \\ 18 & .36 & .14 & 89 \\ 17 & .02 & .22 & 183 \\ 163 & .21 & .30 & 149 \\ 64 & .19 & .28 & 314 \\ 34 & .45 & .42 & 196\end{array}$

(Appendixes continue) 
Appendix B (continued)

\begin{tabular}{|c|c|c|c|c|}
\hline Meta-analytic conclusion & $k$ & $\bar{r}$ & $S D$ & $\begin{array}{c}\text { Document } \\
\text { no. }\end{array}$ \\
\hline \multicolumn{5}{|l|}{ Group processes (continued) } \\
\hline The members of a group influence one another & 108 & .33 & .28 & 285 \\
\hline People who deviate from a group are rejected by that group & 23 & .60 & .37 & 287 \\
\hline Intelligent people are the most active members of a group & 36 & .18 & & 172 \\
\hline \multicolumn{5}{|l|}{ A person who is close to others and central to group communication ... } \\
\hline will be satisfied with the group & 33 & .33 & .00 & 186 \\
\hline will actively participate in the group & 39 & .33 & .05 & 186 \\
\hline is likely to emerge as leader of the group & 33 & .37 & .09 & 186 \\
\hline People who participate in a group are likely to become the leader of that & 72 & 60 & & 268 \\
\hline group & 33 & .55 & .17 & 198 \\
\hline People who are highly esteemed are likely to lead group discussions & 17 & .36 & .16 & 23 \\
\hline Knowledge of others' views causes a group polarization of attitudes & 22 & .44 & .43 & 142 \\
\hline Hearing others' arguments causes a group polarization of attitudes & 12 & .75 & .43 & 142 \\
\hline Dormitory crowding makes residents dissatisfied & 19 & .28 & .15 & 192 \\
\hline Large groups have firmer spatial boundaries than small groups & 58 & .20 & .19 & 187 \\
\hline In social dilemmas, people favor self-interest over group interest & 130 & .06 & & 241 \\
\hline Tough bargaining strategies produce advantageous outcomes & 34 & .20 & .06 & 10 \\
\hline \multicolumn{5}{|l|}{ Negotiators are likely to compromise if they ... } \\
\hline are experienced & 14 & .37 & .28 & 74 \\
\hline have a cooperative personality and a tough opponent & 20 & .37 & .39 & 74 \\
\hline Negotiators sometimes reach mutually disadvantageous agreements & 20 & .20 & .00 & 289 \\
\hline Conversations lack social content if they are computer-mediated & 21 & .09 & .00 & 298 \\
\hline
\end{tabular}

Health psychology

People who receive the most social support are healthy

People who receive the most social support are unhealthy

People who receive the most social support are unhealthy

People who lack social support have high blood pressure

Social support facilitates healthy maternal attitudes and behavior

People who believe they have social support in fact have social support

People with Type A personalities suffer chronic emotional distress

The most socially active people report the highest life satisfaction

Anglo Americans report higher life satisfaction than African-Americans

Married people report higher life satisfaction than others

Women report higher life satisfaction than men

Men report higher life satisfaction than women

When people drink alcohol, they engage in extreme behaviors

When people think they are drinking alcohol...

they engage in extreme behaviors

they engage in illicit social behaviors

People with AIDS suffer more stigma than people with other diseases

People who suffer depression are evaluated negatively

People who suffer depression make their interaction partners feel bad

Disabled students have low status among their peers

People exercise if they are encouraged to exercise

$\begin{array}{rrrr}48 & .19 & & 267 \\ 20 & .08 & .18 & 140 \\ 21 & .22 & .32 & 61 \\ 26 & .27 & .19 & 253 \\ 63 & .16 & .22 & 253 \\ 37 & .30 & .09 & 205 \\ 173 & .21 & .00 & 48 \\ 70 & .40 & .00 & 133 \\ 23 & .26 & & 98\end{array}$

People donate blood if they intend to donate blood and like to do so

\section{Helping behavior}

People are likely to help others when they are in a bad mood People are likely to help others when they are in a good mood Children who are helpful can infer others' motives and thoughts Children who are helpful can infer others' feelings and concerns People act prosocially after seeing prosocial behavior on TV Only children are prosocial in character People are likely to help individuals who depend on them

$\begin{array}{rrrr}85 & .11 & & 46 \\ 61 & .26 & & 43 \\ 22 & .28 & .46 & 296 \\ 14 & .09 & .49 & 296 \\ 108 & .26 & .42 & 134 \\ 26 & .07 & .23 & 90 \\ 72 & .25 & & 33\end{array}$


Appendix B (continued)

\begin{tabular}{lrrrr}
\hline \multicolumn{1}{c}{ Meta-analytic conclusion } & & \multicolumn{2}{c}{$\begin{array}{c}\text { Document } \\
\text { no. }\end{array}$} \\
\hline \multicolumn{1}{c}{ Helping behavior (continued) } & $k$ & $\bar{r}$ & & \\
& & & \\
Rural people are more helpful than urban people & 65 & .11 & 264 \\
Men are more likely than women to help others & 99 & .17 & .20 & 79 \\
Women are more likely than men to perform caretaking tasks for others & 21 & .07 & .09 & 177 \\
Women have more empathy than men & 18 & .37 & .19 & 86 \\
Empathy increases helping behavior & 161 & .15 & .10 & 87 \\
People who are empathetic are nonaggressive & 49 & .10 & .06 & 178 \\
Empathetic people do not act negatively, antisocially, or abusively & 23 & .21 & & 178 \\
\hline
\end{tabular}

Intergroup relations

People prefer their own group to other groups

Minority psychotherapy clients prefer counselors of their own ethnicity

Schoolchildren prefer classmates of their own race

People identify members of their own race better than members of another race

In judging performance, Anglo Americans favor Anglo Americans over African Americans

In judging performance, African Americans favor African Americans over Anglo Americans

People give higher job ratings to Anglo than African Americans

Supervisors rate African Americans by job performance and knowledge

Supervisors rate Anglo Americans by job performance and knowledge

African Americans believe that they have high academic ability

School desegregation raises African Americans' academic achievement

School desegregation raises African Americans' academic achievement

Blacks are slightly more impulsive, aggressive, and mature than Whites

People fuse the visual images of individuals of different races

People perceive less in-group than out-group homogeneity

Prejudice causes discrimination

Men are more likely than women to dislike homosexuals

Men are more likely than women to dislike homosexuals

Men are more likely than women to dislike homosexuals

People prefer young adults to elderly adults

Young people believe that the elderly are unqualified for jobs

Elderly people give equal ratings to young and old job applicants

People attribute negative behaviors to members of stereotyped groups

People associate small groups with negative events

$\begin{array}{llll}137 & .35 & .31 & 188\end{array}$

\section{Law}

A confident eyewitness gives accurate eyewitness testimony

A confident eyewitness gives accurate eyewitness testimony

Eyewitnesses are accurate if they were confident before seeing a lineup

Eyewitnesses who are told that the perpetrator is in a lineup ...

are confident in identifying a perpetrator

are inaccurate in identifying a perpetrator

It is easier to identify a suspect from a lineup than from photographs

If weapons are present at a crime, eyewitnesses have difficulty ... identifying the perpetrator of the crime in a lineup recalling the perpetrator's features

Eyewitnesses are more accurate under some conditions than others

There are individual differences in eyewitnesses' accuracy

Large juries are more likely than small juries to reach a correct verdict

Large juries are more likely than small juries to produce a hung trial

A jury's final verdict is likely to be the verdict a majority initially favored

$\begin{array}{rrrr}35 & .25 & .09 & 36 \\ 30 & .28 & .07 & 262 \\ 9 & .10 & .23 & 63 \\ & & & \\ 10 & .04 & & 266 \\ 19 & .12 & .35 & 266 \\ 28 & .06 & .21 & 62 \\ & & & \\ 19 & .06 & .11 & 265 \\ 10 & .27 & & 265 \\ 552 & .17 & .39 & 254 \\ 173 & .05 & .23 & 254 \\ 10 & .02 & .09 & 240 \\ 15 & .07 & .09 & 240 \\ 13 & .63 & .00 & 171\end{array}$


Appendix B (continued)

\begin{tabular}{|c|c|c|c|c|}
\hline Meta-analytic conclusion & $k$ & $\bar{r}$ & $S D$ & $\begin{array}{c}\text { Document } \\
\text { no. }\end{array}$ \\
\hline \multicolumn{5}{|l|}{ Law (continued) } \\
\hline If a jury is initially split on a verdict, its final verdict is likely to be lenient & 13 & 63 & .00 & 171 \\
\hline Juries are more influenced by credible than noncredible witnesses & 8 & .17 & & 304 \\
\hline Juries are harsher on African American than Anglo American defendants & 19 & .09 & .03 & 280 \\
\hline Jurors are harsh on poor, unattractive African American male defendants & 131 & .05 & .11 & 175 \\
\hline Jurors are harsh if the victim is an attractive Anglo American female & 55 & .04 & .00 & 175 \\
\hline Jurors who are high in authoritarianism favor harsh sentences & 34 & .16 & .09 & 202 \\
\hline In sexual assault cases, female jurors are harsher than male jurors & 36 & .16 & .00 & 248 \\
\hline Men, more than women, believe that people get what they deserve & 39 & .06 & .06 & 206 \\
\hline Exposure to pornography encourages acceptance of rape myths & 24 & .10 & .09 & 8 \\
\hline The people most tolerant of rape are aging, lower-class men of color & 61 & .23 & .14 & 14 \\
\hline \multicolumn{5}{|l|}{ A woman is likely to be held responsible for being raped if she... } \\
\hline was previously acquainted with her attacker & 14 & .16 & .22 & 302 \\
\hline is of questionable character & 17 & .20 & .13 & 302 \\
\hline
\end{tabular}

Leadership

In comparison with subordinates ...

leaders are older

leaders are more intelligent

leaders are more intelligent

leaders are more intelligent

leaders are more extroverted

leaders are more extroverted

$\begin{array}{rrrr}13 & .21 & & 273 \\ 196 & .25 & & 172 \\ 17 & .28 & & 273 \\ 13 & .38 & .03 & 165 \\ 119 & .15 & & 172 \\ 10 & .10 & .19 & 165\end{array}$

Leaders are most effective if they ...

have charisma

have charisma

stimulate subordinates and show them consideration

offer rewards that are contingent on performance

avoid making unnecessary changes

People are less satisfied with autocratic than democratic leaders

People are more productive under autocratic than democratic leaders

In large groups, leaders initiate structure and are inconsiderate

People are satisfied with leaders who initiate structure

People perform well under leaders who initiate structure

People are satisfied with leaders who show them consideration

People perform well under leaders who show them consideration

Good leader-subordinate relations promote subordinate satisfaction

Good leader-subordinate relations promote subordinate productivity

In favorable situations, task-oriented leaders are most effective

In favorable situations, task-oriented leaders are most effective

In favorable situations, task-oriented leaders are most effective

In favorable situations, task-oriented leaders are most effective

In favorable situations, task-oriented leaders are most effective

In unfavorable situations, task-oriented leaders are most effective

In unfavorable situations, task-oriented leaders are most effective

In unfavorable situations, task-oriented leaders are most effective

In unfavorable situations, task-oriented leaders are most effective

In intermediate situations, morale-oriented leaders are most effective

In intermediate situations, morale-oriented leaders are most effective

In intermediate situations, morale-oriented leaders are most effective

In intermediate situations, morale-oriented leaders are most effective

In intermediate situations, morale-oriented leaders are most effective

There are sex differences

Women are more effective leaders than men

Men are more effective leaders than women

$\begin{array}{llll}49 & .54 & .14 & 107 \\ 47 & .62 & .25 & 166 \\ 86 & .52 & .01 & 166 \\ 43 & .34 & .27 & 166 \\ 41 & .04 & .20 & 166 \\ 28 & .23 & .18 & 110 \\ 23 & .02 & .07 & 110 \\ 16 & .07 & .08 & 185 \\ 90 & .25 & .17 & 313 \\ 87 & .13 & .28 & 313 \\ 88 & .46 & .20 & 313 \\ 88 & .19 & .27 & 313 \\ 60 & .53 & .25 & 111 \\ 65 & .28 & .24 & 111 \\ 58 & .28 & .23 & 218 \\ 57 & .18 & .65 & 116 \\ 40 & .24 & & 275 \\ 18 & .32 & & 245 \\ 11 & .54 & & 100 \\ 22 & .41 & .21 & 218 \\ 20 & .44 & .61 & 116 \\ 13 & .45 & & 100 \\ 12 & .44 & & 245 \\ 69 & .13 & .54 & 116 \\ 57 & .29 & .06 & 218 \\ 50 & .36 & & 245 \\ 43 & .31 & & 275 \\ 30 & .20 & & 100 \\ 76 & .01 & .13 & 83 \\ 18 & .02 & .12 & 71 \\ & & & \end{array}$


Appendix B (continued)

\begin{tabular}{llllll}
\hline & & \multicolumn{2}{c}{ Document } \\
Meta-analytic conclusion & $k$ & $\bar{r}$ & $S D$ & no. \\
\hline
\end{tabular}

Leadership (continued)

Men are more likely than women to ...

be evaluated favorably as leaders

be evaluated favorably as leaders

remain subordinates in social groups

emerge as leaders in other groups

be task oriented, solitary, and autocratic as leaders

be non-task oriented and autocratic as school principals

Methodology

Psychological ratings are reliable

\begin{tabular}{rrrr}
114 & .02 & .16 & 84 \\
71 & .04 & & 15 \\
15 & .09 & .08 & 81 \\
169 & .16 & .17 & 81 \\
329 & .01 & .35 & 80 \\
117 & .02 & .18 & 82 \\
\hline
\end{tabular}

Measures of communication anxiety are reliable across situations

Measures of subjective well-being are valid

Self-evaluations of ability are valid

Self-evaluations of performance are valid

People who report being feminine exhibit feminine behaviors

People who report being masculine exhibit masculine behaviors

Men report greater masculinity than women

Women report greater femininity than men

Persuasive fear appeals effectively arouse fear

Illusion of control manipulations changes perceptions of control

Experimental mood induction procedures effectively alter mood

Experimental mood induction procedures effectively alter mood

When assessed with a bogus pipeline measure, people...

acknowledge undesirable attitudes

acknowledge smoking

deny using drugs

People are most likely to respond to surveys if they ...

are greeted face-to-face, rather than through the mail

are assured that their responses will be confidential are given monetary gratuities are given return postage receive prior notice, follow-ups, and monetary incentives

$\begin{array}{rrrr}26 & .07 & & 139 \\ 64 & .07 & & 256 \\ 74 & .12 & .08 & 51 \\ 30 & .08 & .06 & 104 \\ 85 & .19 & .30 & 137 \\ 6 & .03 & .00 & 22 \\ 184 & .07 & .09 & 319 \\ & & & \\ 39 & .03 & & 235 \\ 37 & .11 & & 235 \\ 34 & .10 & & 235 \\ 26 & .12 & & 235 \\ 164 & .08 & & 311 \\ 38 & .00 & .00 & 2\end{array}$

People who volunteer to participate in research are unusually... young intelligent

low in authoritarianism high in sensation-seeking

Taking a pretest improves a person's score on a posttest People act differently if they believe they are being studied

Motivation

External rewards increase productivity

External rewards decrease the amount of free time spent on a task

External rewards decrease intrinsic motivation

External rewards increase intrinsic motivation

External rewards decrease intrinsic motivation in some circumstances

External rewards increase intrinsic motivation in other circumstances

People who have high achievement motivation achieve a lot

African Americans have less achievement motivation than Anglos

Only children have high achievement motivation

Situational factors influence a person's willingness to wait for a reward

Men are more motivated than women to manage businesses

Boys are more competitive than girls

$\begin{array}{rllr}13 & .17 & .04 & 310 \\ 17 & .24 & .05 & 310 \\ 88 & .16 & .07 & 237 \\ 148 & .03 & .18 & 42 \\ 99 & .22 & & 286 \\ 127 & .09 & & 286 \\ 383 & .18 & .17 & 261 \\ 26 & .10 & .13 & 58 \\ 43 & .08 & .24 & 90 \\ 9 & .44 & .26 & 108 \\ 51 & .11 & .08 & 76 \\ 95 & .03 & .11 & 274\end{array}$




\section{Nonverbal communication}

Nonverbal behavior quickly conveys accurate information about the actor

The people who are good at understanding others' nonverbal behavior ... have dominant personalities

have high socioeconomic status are from nonexpressive families are intelligent, trusting, well adjusted, and cognitively complex

People like individuals who make eye contact, smile, and lean forward

People can recognize facial expressions of emotion across cultures

People can recognize facial expressions of emotion across cultures

Emotions are expressed more on the left than the right side of the face

Smiling increases happiness

People judge deception accurately

People judge deception accurately from nonverbal cues

People judge deception accurately from verbal cues

People judge deception from certain visible cues (like gaze aversion)

People judge deception from certain audible cues (like high pitch)

People who are lying have wide pupils, blink a lot, and don't move their head

People who are lying have wide pupils, blink a lot, and don't move their head

People who are lying give short responses, and offer negative, irrelevant remarks

People who are lying give short responses, and offer negative, irrelevant remarks

There are sex differences: Females smile more than males

In comparison with women, men maintain more physical distance from others

In comparison with males, females gaze more at others

Men touch women more than women touch men

Women are more skilled at expressing emotion than men

In comparison with men, women have more understanding of nonverbal behavior

In comparison with men, women have more understanding of nonverbal behavior

Women are more sensitive than men to facial cues

Women are more sensitive than men to vocal cues

Women are more sensitive than men to nonverbal body cues

\begin{tabular}{|c|c|c|c|}
\hline 38 & .41 & .38 & 12 \\
\hline 15 & .29 & .43 & 126 \\
\hline 17 & .15 & .08 & 126 \\
\hline 5 & .20 & .00 & 120 \\
\hline 230 & .10 & .11 & 64 \\
\hline 75 & .26 & & 290 \\
\hline 34 & .45 & & 238 \\
\hline 23 & .53 & & 243 \\
\hline 65 & .19 & .23 & 257 \\
\hline 16 & .34 & .04 & 173 \\
\hline 16 & .40 & .21 & 67 \\
\hline 14 & .23 & .43 & 66 \\
\hline 14 & .39 & .14 & 66 \\
\hline 31 & .17 & & 65 \\
\hline 19 & .19 & .27 & 321 \\
\hline 110 & .07 & & 65 \\
\hline 91 & .12 & .31 & 321 \\
\hline 92 & .10 & & 65 \\
\hline 68 & .15 & .38 & 321 \\
\hline 20 & .23 & & 125 \\
\hline 62 & .25 & & 123 \\
\hline 41 & .29 & & 125 \\
\hline 10 & .04 & .50 & 270 \\
\hline 42 & .28 & & 123 \\
\hline 64 & .21 & & 123 \\
\hline 46 & .17 & .18 & 122 \\
\hline 85 & .16 & & 234 \\
\hline 68 & .06 & & 234 \\
\hline 60 & .11 & & 234 \\
\hline
\end{tabular}

Personality

Personality characteristics are stable over time

People agree with one another about others' personality characteristics

Introverts are more vigilant than extroverts

Introverts are less intelligent than extroverts

Unintelligent people have strong reactions to stress

Intelligent people are popular

Sociable, intelligent children are popular with their peers

Aggressive, withdrawn children are rejected by their peers

Nonaggressive, unsociable children are neglected by their peers

Aggressive, sociable children cause controversy among their peers

People who are optimistic are usually in a good mood

People with low self-esteem often feel bad

People with low self-esteem often suffer communication apprehension

Students who have high self-esteem achieve a lot

Students who perform well have high perceived self-efficacy

Students who perform poorly are external in locus of control

Students who perform poorly are external in locus of control

$\begin{array}{rllr}106 & .66 & & 246 \\ 36 & .16 & & 151 \\ 216 & .08 & .07 & 1 \\ 100 & .06 & .03 & 159 \\ 217 & .09 & .08 & 1 \\ 38 & .10 & & 172 \\ 176 & .05 & .20 & 204 \\ 194 & .03 & .28 & 204 \\ 182 & .06 & .11 & 204 \\ 63 & .18 & .26 & 204 \\ 42 & .43 & .13 & 16 \\ 6 & .46 & .22 & 300 \\ 31 & .35 & & 167 \\ 1,136 & .21 & .47 & 132 \\ 38 & .38 & .04 & 199 \\ 261 & .23 & .39 & 148 \\ 67 & .18 & .41 & 101\end{array}$


Appendix B (continued)

Meta-analytic conclusion

Personality (continued)

People who suffer depression are external in locus of control People who suffer depression are external in locus of control Shrewd, manipulative people are external in locus of control Intrinsically religious people do not make selfish use of religion

Socially anxious people...

blush and have rapid heartrate

have negative self-focus, and worry about being evaluated

stutter, pause before speaking, and avoid others

A person's ability to process messages is disrupted by anxiety

Only children are highly sociable

There are sex differences: men have higher self-esteem than women

Women experience more anxiety than men

Women are more anxious than men about communicating with others

Women are more likely than men to be external in locus of control

Men are more assertive than women

Girls develop mature personalities at an earlier age than boys

\section{Relationships}

Romantic partners resemble one another in physical attractiveness

People who are physically attractive are judged to have positive traits

People who are physically attractive are judged to have positive traits

People who are physically attractive are judged to have positive traits

People who are physically attractive have positive traits

People who are physically attractive are judged to be intelligent

People who are physically attractive are intelligent

Physically attractive women are popular

Physically attractive men are popular

People engage in self-disclosure to people they like

People who disclose a lot about themselves are liked by others

Interpersonal attraction is reciprocated

Friends interact more positively with one another than nonfriends

Adolescents use contraceptives if they...

receive social support

have a good relationship with their partner

Spouses who treat one another well are satisfied with their marriage

People who relate well to their children relate well to their spouse

People involved in intimate violence give undesirable self-descriptions

There are sex differences in relationships: Women are more likely than men to engage in self-disclosure to others

In comparison with women, men are more likely to rate ...

physical attractiveness as important in romantic attraction

physical attractiveness as important in mate selection

similarity as unimportant in romantic attraction

In selecting a mate, women attach more importance than men to...

intelligence

socioeconomic status

character

Women are attracted to taller men; men are attracted to shorter women

Men are more likely than women to...

favor premarital sex

report being aroused by sexual stimuli

be sexually permissive

report sexual intercourse

report petting

be satisfied if they remarry

$\begin{array}{rrrr}97 & .32 & .33 & 26 \\ 15 & .19 & .11 & 223 \\ 20 & .34 & & 180 \\ 34 & .06 & .15 & 72 \\ & & & \\ 28 & .36 & & 217 \\ 232 & .46 & & 217 \\ 120 & .40 & & 217 \\ 18 & .34 & .14 & 221 \\ 54 & .00 & .22 & 220 \\ 88 & .06 & .06 & 97 \\ 64 & .13 & .08 & 97 \\ 22 & .10 & & 167 \\ 39 & .06 & .16 & 97 \\ 52 & .08 & .19 & 97 \\ 113 & .14 & .12 & 53\end{array}$

Document

no.

$k$

$\bar{r}$

SD 
Appendix B (continued)

\begin{tabular}{|c|c|c|c|c|}
\hline Meta-analytic conclusion & $k$ & $\bar{r}$ & $S D$ & $\begin{array}{c}\text { Document } \\
\text { no. }\end{array}$ \\
\hline \multicolumn{5}{|l|}{ Social cognition } \\
\hline People who engage in a behavior believe that the behavior is common & 115 & .31 & .17 & 184 \\
\hline People who engage in a behavior believe that the behavior is common & 84 & .34 & .21 & 193 \\
\hline The members of a majority will underestimate the size of their majority & 67 & .33 & .39 & 193 \\
\hline The members of a minority will overestimate the size of their minority & 67 & .49 & .42 & 193 \\
\hline A majority consisting of $50 \%-62 \%$ of a group will overestimate its size & 47 & .09 & & 118 \\
\hline Once people know something, they believe they "knew it all along" & 122 & .17 & .14 & 50 \\
\hline Impressions are based on stereotyping & 40 & .19 & & 163 \\
\hline Impressions are based on individuals' special characteristics & 40 & 69 & & 163 \\
\hline People know how well they are liked by others & 12 & .30 & & 152 \\
\hline For social categorization, person categories are most often used & 26 & .00 & .20 & 252 \\
\hline Accuracy in rating others is reduced by biases, like being too lenient & 240 & .05 & & 201 \\
\hline \multicolumn{5}{|l|}{ People are most likely to recall information from social memory if ... } \\
\hline it is inconsistent with their expectations & 165 & .11 & .15 & 231 \\
\hline it is consistent with their expectations & 65 & .03 & .33 & 263 \\
\hline it is consistent with their attitudes & 63 & .18 & .44 & 229 \\
\hline it is consistent with their stereotypes & 26 & .17 & .23 & 109 \\
\hline they think about how the information relates to them & 129 & .24 & .19 & 284 \\
\hline their mood is the same as when they learned the information & 100 & .21 & .37 & 295 \\
\hline People remember positive events when they are elated & 22 & .04 & .00 & 174 \\
\hline People remember negative events when they are depressed & 35 & .04 & .00 & 174 \\
\hline People normally remember more positive than negative events & 25 & .07 & .00 & 174 \\
\hline Memory is positively related to an individual's need for cognition & 19 & .17 & .19 & 41 \\
\hline Women are more accurate than men at recognizing people's faces & 17 & .16 & & 123 \\
\hline
\end{tabular}

Social influence

In the presence of others ...

people become physiologically aroused people become physiologically aroused people show a social facilitation of simple task performance people show a social impairment of complex task performance

Children perform well on tests that are administered by people they know

People who get a foot-in-the-door by securing compliance to a small request are likely to gain compliance to a larger request

People who get a foot-in-the-door by securing compliance to a small request are likely to gain compliance to a larger request

People who get a foot-in-the-door by securing compliance to a small request are likely to gain compliance to a larger request

People who get a door-in-the-face by securing refusal to a large request are likely to gain compliance to a smaller request

People who get a door-in-the-face by securing refusal to a large request are likely to gain compliance to a smaller request

People who get a door-in-the-face by securing refusal to a large request are likely to gain compliance to a smaller request

People show a conformity to others' incorrect answers

Women are more likely than men to conform to others' actions

Women are more susceptible to social influence than men

People are unlikely to express their opinions without others' support

People are likely to jaywalk if they see another person jaywalk

People who engage in ingratiation are well-liked

It is easiest to influence a person who...

has low self-esteem

has moderate self-esteem

has little intelligence

The higher a person's status, the greater the person's social influence

$\begin{array}{rrrr}82 & .08 & .30 & 29 \\ 49 & .04 & .52 & 189 \\ 266 & .11 & .24 & 29 \\ 201 & .16 & .30 & 29 \\ 34 & .16 & .18 & 106 \\ & & & \\ 85 & .16 & & 24 \\ & & & \\ 77 & .13 & .00 & 99 \\ & & & \\ 34 & .11 & .37 & 69 \\ & & & \\ 56 & .07 & .00 & 99 \\ & & & \\ 24 & .08 & .30 & 69 \\ & & & \\ 17 & .10 & .07 & 208 \\ 133 & .42 & .12 & 30 \\ 38 & .06 & .07 & 56 \\ 148 & .08 & .26 & 78 \\ 25 & .05 & .05 & 113 \\ 25 & .16 & .07 & 191 \\ 69 & .10 & .25 & 114 \\ & & & \\ 38 & .11 & .21 & 227 \\ 41 & .09 & .13 & 227 \\ 10 & .20 & .25 & 227 \\ 9 & .18 & .33 & 181\end{array}$


Appendix B (continued)

\begin{tabular}{|c|c|c|c|c|}
\hline Meta-analytic conclusion & $k$ & $\bar{r}$ & $S D$ & $\begin{array}{c}\text { Document } \\
\text { no. }\end{array}$ \\
\hline \multicolumn{5}{|c|}{ Social influence (continued) } \\
\hline \multicolumn{5}{|l|}{ Subordinates are most productive and satisfied if their supervisors ... } \\
\hline use expert or referent power & 52 & .27 & .26 & 49 \\
\hline use legitimate or reward power & 52 & .04 & .25 & 49 \\
\hline refrain from using coercive power & 26 & .18 & .22 & 49 \\
\hline \multicolumn{5}{|c|}{ In comparison with majority influence, minority social influence produces . . . } \\
\hline more change in private behaviors unrelated to the influence & 12 & .02 & .17 & 316 \\
\hline less change in other behaviors & 26 & .15 & .12 & 316 \\
\hline
\end{tabular}

Note. Italicized terms are those that appear in the Manstead and Hewstone (1995) encyclopedia.

Received October 6, 2002

Revision received January 10, 2003

Accepted February 10, 2003 